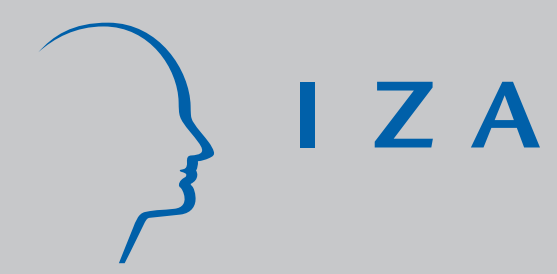

IZA DP No. 672

Self-Selection, Earnings, and Out-Migration:

A Longitudinal Study of Immigrants to Germany

Amelie Constant

Douglas S. Massey

December 2002 


\title{
Self-Selection, Earnings, and Out-Migration: A Longitudinal Study of Immigrants to Germany
}

\author{
Amelie Constant \\ University of Pennsylvania \\ and IZA Bonn \\ Douglas S. Massey \\ University of Pennsylvania
}

\section{Discussion Paper No. 672 \\ December 2002}

\author{
IZA \\ P.O. Box 7240 \\ D-53072 Bonn \\ Germany \\ Tel.: +49-228-3894-0 \\ Fax: +49-228-3894-210 \\ Email: iza@iza.org
}

This Discussion Paper is issued within the framework of IZA's research area Mobility and Flexibility of Labor. Any opinions expressed here are those of the author(s) and not those of the institute. Research disseminated by IZA may include views on policy, but the institute itself takes no institutional policy positions.

The Institute for the Study of Labor (IZA) in Bonn is a local and virtual international research center and a place of communication between science, politics and business. IZA is an independent, nonprofit limited liability company (Gesellschaft mit beschränkter Haftung) supported by the Deutsche Post AG. The center is associated with the University of Bonn and offers a stimulating research environment through its research networks, research support, and visitors and doctoral programs. IZA engages in (i) original and internationally competitive research in all fields of labor economics, (ii) development of policy concepts, and (iii) dissemination of research results and concepts to the interested public. The current research program deals with (1) mobility and flexibility of labor, (2) internationalization of labor markets, (3) welfare state and labor market, (4) labor markets in transition countries, (5) the future of labor, (6) evaluation of labor market policies and projects and (7) general labor economics.

IZA Discussion Papers often represent preliminary work and are circulated to encourage discussion. Citation of such a paper should account for its provisional character. A revised version may be available on the IZA website (www.iza.org) or directly from the author. 


\section{ABSTRACT \\ Self-Selection, Earnings, and Out-Migration: A Longitudinal Study of Immigrants to Germany*}

In this paper we seek to deepen understanding of out-migration as a social and economic process and to investigate whether cross-sectional earnings assimilation results suffer from selection bias. To model the process of out-migration we conduct a detailed event history analysis of men and women immigrants in Germany. Our 14-year longitudinal study reveals that emigrants are negatively selected with respect to occupational prestige and to stable full time employment. Our results show no selectivity with respect to human capital, earnings, or gender. The likelihood of return migration is strongly determined by the range and nature of social attachments to Germany and origin countries, and grows higher toward retirement. This selective emigration, however, does not appear to distort cross-sectional estimates of earnings assimilation.

JEL Classification: J61, J2, C4

Keywords: return migration, immigrant assimilation, event history

Corresponding author:

Amelie Constant

IZA

P.O. Box 7240

D-53072 Bonn

Germany

Fax: +492283894 180

Email: aconstan@pop.upenn.edu

\footnotetext{
* This study has been made possible through various research visits to DIW Berlin and IZA in Bonn. We are grateful for the access to the data, and many useful comments on various drafts by Klaus $F$. Zimmermann. The paper was presented at the annual conference of the Population Association of America in Atlanta, and research seminars at Princeton University and IZA, Bonn. We wish to thank many participants for stimulating discussions and useful comments.
} 
By the end of the second millennium the immigrant population in Germany had risen to more than $10 \%$ while the majority of immigrants in Germany, the guestworkers, ${ }^{1}$ had been living in Germany for more than a quarter of a century. Still, guestworkers remain a large and distinct group of legal immigrants, the majority of whom are Turks. As the immigrant population in Germany has grown, researchers have found that immigrant earnings remain far below those of the native Germans with few prospects of achieving parity anytime soon.

Beginning in the late 1950's, Germany experienced a massive migration similar in magnitude to the "Great Migration" to the US in the early 1900s. After the erection of the Berlin wall in 1961, especially, German employers recruited millions of foreigners to work in German factories and the service sector. According to bilateral treaties these migrants were to relieve Germany of short term labor shortages and were expected to return to their homelands afterwards. ${ }^{2}$ At the same time, the guestworkers themselves were guided by short term migratory intentions. Initially, at least, they intended to migrate to Germany to earn enough money to improve their economic situation at home and then return to their 'native soil' within five years. Up until the halt of guestworker recruitment in 1973, migrants were primarily young single men, and those who were married were not accompanied by their families. After 1973, however, virtually all migration to Germany occurred through family reunification.

\footnotetext{
${ }^{1}$ Guestworkers and immigrants are synonymous terms in this paper; they include both the foreign-born and their offsprings who are born in Germany. They all are legal residents, and some are even German citizens.

${ }^{2}$ Bilateral treaties for recruitment were signed with Italy in 1955, Spain and Greece in 1960 , Turkey in 1961, Portugal in 1964, and Yugoslavia in 1968.
} 
The enlargement of the European Union in the 1980's and 1990's allowed certain national origin groups to live and work legally in Germany. Among former guestworkers, Italians, Spaniards, and Greeks acquired full labor and residence rights. The fall of the Iron Curtain in the late 1980's also prompted a new wave of immigration by roughly 4 million Aussiedlerfrom Eastern Europe, ethnic German immigrants ${ }^{3}$ who according to the German constitution had the right to "return" to Germany as citizens. They came mainly from Poland, Romania, and the former USSR.

Except for the Aussiedler, most immigrant groups were guided by a powerful ideology of return migration. Overall, Bohning (1981) estimates that more than two thirds of foreign workers admitted to the Federal Republic of German between 1961 and 1976 eventually returned home. The rates of return migration were particularly high for migrants from EU countries, with 9 of 10 Italians, 8 of 10 Spaniards, and 7 of 10 Greeks ultimately going back. Those migrants who did not have the right to freely come and go returned in much smaller numbers. Over the same period, only 5 of 10 Yugoslavs and 3 of 10 Turks returned home. As a result, 30 years after recruitment ended, official statistics reveal that "guests" still constitute more than $8 \%$ of the German workforce, although many still maintain that eventually they will return "home" when asked.

Research on the out-migration ${ }^{4}$ of immigrants is important for at least four reasons. First, understanding emigration is pivotal in assessing the relative success of immigrants in the host country labor market. Regardless of whether immigrants are positively or

\footnotetext{
${ }^{3} \mathrm{~A}$ small part of this group are the East Germans or Übersiedler.

${ }^{4}$ Emigration, return migration, remigration, and repatriation, are synonymous terms in the literature and in this paper.
} 
negatively selected, the selective character of emigration amplifies their initial selection and can, therefore, undermine the validity of cross-sectional studies to yield erroneous estimates of assimilation processes (Borjas 1985). Second, it is also important to take selective emigration into account when measuring the economic effect of immigration on natives. Third, selective patterns of emigration may have significant fiscal implications (Reagan and Olsen 2000; Duleep 1994), as the characteristics of immigrants are tied to use of the social welfare system. Finally, more accurate research on emigration can improve the ability to forecast trends in immigration.

Decisions with respect to return migration are inherent in the migratory career. From the moment a person first migrates internationally, he or she is confronted with the decision of whether to stay in the destination country, move to another host country, or return home. Here we define out-migration as movement from the host country back to the native country and conceptualize return as the last phase in the larger social process of migration (Massey 1987).

In this paper we seek to identify the underlying economic and social determinants of out-migration and to gauge its effect on the earnings of immigrants observed at any point in time. We organize our analysis around two basic research questions. First, who are the immigrants who choose to go back to their home country, to what degree are they self-selected and, if selected, do they tend to come from the upper or lower end of the socioeconomic distribution? Second, does selective out-migration bias the estimates of cross-sectional earnings regressions---that is do immigrants who stay in Germany earn higher or lower wages than those who returned? 
Our paper extends previous research by studying life cycle events and earnings among both male and female immigrants, and by modeling actual return migration rather than intentions. To achieve these goals we undertake a detailed discrete time event history analysis using a multinomial logit specification that models the probability of return at each point in time as a function of human capital, labor market characteristics, demographic traits, and social and psychological ties to places of origin and destination, We allow for the heterogeneity of motives by controlling for remittances and also hold constant period and geographical effects.

Our data come from the German Socio-Economic Panel (GSOEP). Our analysis of data from the panel's first 14 years suggest an emigration rate of $18 \%$ among foreign origin workers. Our analysis of 33,493 person years of information confirms that return migration is highly selective, although the probability is relatively low in any given year. The odds of returning are highest for immigrants who are not attached to paid employment in Germany and who have maintained strong ties to the country of origin. We also find that sending remittances is a very important and positive determinant of return migration. At the same time, we find that migrants who have created and cultivated strong ties in Germany are less likely to return to their native countries.

Cross-sectional analyses of immigrant earnings suggest an ongoing process of economic assimilation consistent with human capital theory. More importantly, we find that estimates do not differ significantly once self-selected out-migrants are added back into the panel. In general, immigrant earnings increase with education, age, hours of work, occupational prestige, and years of residence in Germany (though only after 15 years) and are significantly higher for males than females. 


\section{PRIOR STUDIES OF RETURN MIGRATION}

A wealth of research has documented relatively high emigration rates that vary considerably by nationality. Most empirical studies have been gender blind, considering only male immigrants. Historically, according to U.S. Social Security actuarial assumptions, $30 \%$ of all legal immigrants to the United States ultimately returned home, $83 \%$ during their first ten years and $17 \%$ thereafter (Duleep 1994). ${ }^{5}$ In the 1960 s, returning immigrants constituted about one third of arriving legal U.S. immigrants and emigration rates were higher for more recent immigrants (Warren and Peck 1980). In the 1970's, annual emigration rates dropped to around $27 \%$, and most emigrants were found to leave the country within ten years of their arrival (Warren and Kraly 1985).

Jasso and Rosenzweig (1982) found that emigration rates varied substantially by nationality (ranging from $20 \%$ to $50 \%$ ) and concluded that both proximity to the United States and the relative attractiveness of the home country were good predictors of emigration. Another study of legal US. Immigrants found that between 1960 and 1980 European immigrants were the most likely to emigrate, Asian immigrants were least likely, and immigrants from the Western Hemisphere were in-between (Jasso and Rosenzweig 1990). In the 1980 's, emigration rates were lower than before but still varied substantially by nationality, ranging from 3.5\% for Asians to 34.5\% for North Americans (Borjas and Bratsberg 1994).

With regard to the quality of those who return, research has documented that emigrants are quite self-selected, albeit with conflicting results on the nature of that

\footnotetext{
${ }^{5}$ The Census Bureau's projections for the years 1992-2050, based on the assumption that high levels of immigration are associated with low emigration rates, imply a much lower emigration rate of 15.38 percent (Duleep (1994)).
} 
selection. Jasso and Rosenzweig (1988) found that highly skilled immigrants were most likely not to naturalize and thus had a higher probability of return migration. In sharp contrast, Borjas' (1989) longitudinal study of immigrant scientists and engineers and Massey's (1987) study of Mexican laborers found that out-migrants tended to be the least successful economically. Likewise, Lindstrom and Massey (1994) found that Mexican emigrants were negatively selected with respect to both wages and human capital, but Chiswick (1986b) found little evidence that emigration was selective, at least with respect to schooling. Reagan and Olsen (2000) likewise found no evidence for a skill bias in return migration.

These conflicting findings are explained by the theoretical analysis of Borjas and Bratsberg (1994), who argue that the direction of selection in out-migration depends on whether the immigrants themselves were positively or negatively selected originally. If immigrants were positively selected initially, then return immigrants tend to be the worst of the best; but if they were negatively selected, they tend to be the best of the worst. These theoretical predictions were verified by Ramos (1992) in his study of Puerto Ricans in the U.S. He found that migrants from the island were generally negatively selected, but that returnees were drawn from the most skilled among them.

Reagan and Olsen's (2000) study of both male and female out-migrants did not find any gender differentials, but they did find a lower likelihood of emigration among those who arrived at younger ages, those with higher potential wages, those with more years of U.S. residence, and those who had participated in U.S. social welfare programs. They also found that Mexicans and immigrants with a college degree were more likely to emigrate. Duleep (1994) found a bimodal pattern of migration over time characterized by an early 
peak of "mistaken migrants" returning soon after entry and a later peak of retirement migrants leaving after withdrawal from the labor force in old age. Like other researchers, she found that additional years of U.S. residence lowered the probability of emigration and that rates were highest for Western European countries, lower for Third World countries, and lowest for refugees.

Research on the rate and selectivity of emigration from countries other than the U.S. has also produced conflicting results. For example, Irish return migrants, compared with those who stay abroad and non-migrants, are positively selected for education (Barrett and Trace 1998), while Egyptian return migrants are negatively selected with respect to skills (Bauer and Gang 1998). Contrary to studies in the U.S., Bauer and Gang (1998) also found that additional time spent abroad and access to social and informational networks shortened the duration of foreign trips, while remittances increased it. For Sweden, Edin et al. (2000) also document the non randomness of return migration, while they distinguish economic from political migrants. Their longitudinal study finds that economic migrants are more likely to return compared to political migrants, and within these two groups of immigrants, those who return are the least successful economically; that is, emigrants earn less and participate less in the labor market. For Sweden, therefore, economic assimilation is overestimated and can be as high as 90 percent for certain immigrant groups.

In Germany, the few studies on return migration are based on selected subsamples of the immigrant population and focus on the self-reported expected durations of stay rather than actual return migration. Overall, these studies suggest that more integrated guestworkers are less likely to return. Dustmann (1993), in his theoretical life-cycle model with endogenous return intentions, compared circumstances at home and abroad and 
found that return may occur even without changes in the wage differential. He estimated a cross-sectional regression of male return intentions using as predictors various indicators of integration, such as years since migration, speaking German, being married to a German, and having young children. These factors generally prolonged the intended duration of stay, although as usual it varied substantially by nationality.

Based on the first six waves of the GSOEP, Schmidt's (1994) study of blue collar immigrants found an emigration rate of $21 \%$ based on the assumption that panel attrition was independent of return migration. He also found that return probabilities decreased with education, that age was convex with respect to the odds of return, and that additional years since migration did reduce return propensities. Like others, he found significant cross national differences and much higher odds of return when the spouse remained abroad.

Steiner and Velling's (1994) study of male and female household heads emphasized permanent and temporary intentions of staying. They found that the duration of intended stay increased with years-since-migration, higher education, speaking German, property ownership, feeling good in Germany, and the presence of young children. Having children in the home country decreased the intended duration of stay as did remitting and being unemployed. They also found that the probability of return increased at retirement but could not find any gender effects. In a related study on return migration for purposes of family reunification, Velling (1994) found no effects of gender, education, nationality, or years since migration. Instead, he found that less economically successful immigrants returned home first and that emigration was less likely for older household heads and more likely for remitters. 
If there a synopsis can be gleaned from the literature on return migration, it is that return migration is a rather complicated socioeconomic process whose degree and direction of selectivity varies by national origin and depends on the selectivity of the original immigration, conditions in sending and receiving countries, socioeconomic characteristics, and other unknown and perhaps unobservable factors.

\section{THEORY AND MODEL SPECIFICATION}

Our conceptualization of migration decision-making draws upon both economics and sociology. Economic theory posits that rational self-interested agents migrate wherever the expected present value of total benefits is greater than the total costs of migration, subject to information constraints. Total benefits include those that are pecuniary (higher earnings) and non pecuniary (family and cultural ties, better climate, sentimental bonds with a region, and political regimes). Similarly, costs include the direct costs of moving (out-of-pocket expenses), opportunity costs (income foregone while moving), and psychic costs (the psychological burden leaving familiar surroundings and adapting to a new culture and language).

Sociology has emphasized the importance of social capital in promoting migration, where social capital refers to migration-promoting resources extracted from interpersonal networks that are maintained and reinforced by a constant circulation of people, goods, information, and capital between sending and receiving communities (Massey (1987)). Social capital helps to explain why migration may occur even in the absence of significant changes in international wage differentials.

The theory of return migration is very much like the theory of first migration to another country, with three important differences. First, return migrants are inherently more 
prone to move because they have already moved once. Second, with regard to both the origin and destination countries, return migrants have more accurate information. They know the wage distribution, the language, the culture, and the climate of their native country, but also understand the realities of the host country. Third, higher wages and employment opportunities at home are neither a necessary nor a sufficient condition for return migration. Instead, familial and cultural considerations are relatively more important in return decisions. Indeed, emigrants might decide to return despite a widening wage gap.

Prior theoretical work on emigration suggests that return migrants can come from either the upper or lower end of the socioeconomic distribution. The main theoretical debate hinges upon the quality of the emigrants and their progress in the host country. Specifically, the question is whether wage-experience earnings trajectories estimated by Chiswick and others using cross-sectional data actually reflect the underlying process of economic assimilation experienced by real cohorts, or whether they reflect the changing selectivity of migration across successive cohorts, or perhaps a selective process of return migration wherein economic failures steadily return home.

At each period during their migrant career immigrants are faced with the dilemma of choosing to stay in the host country as immigrants or to return to their homeland, ${ }^{6}$ and they maximize utility gained from the attributes of the choice they make. We assume a utility maximization model where rational individuals are assumed to have preferences over a set of $j$ different alternatives as:

$$
U(\text { alternative } J)=\beta_{j} x_{j}+\epsilon_{j}
$$

\footnotetext{
${ }^{6}$ The option of moving on to a third country is not considered here.
} 
where $\epsilon$ is the random error associated with that choice. Then $Y$ is observed for choice $j$ if:

$$
U(\text { alternative } J)>U(\text { alternative } k) \quad \forall j \neq k
$$

The foregoing equation is the deciding factor for migration. The disturbances are assumed to be independently and identically distributed as a log Weibull distribution. Then, the choice probabilities, assuming a logistic distribution, are: ${ }^{7}$

$$
P(Y=j \mid X)=\frac{e^{\beta_{j} X_{i}}}{1+\sum_{k=0}^{K-1} e^{\beta_{k} X_{i}}}
$$

where $j$ indexes the alternative choices, $j=0,1, \ldots, \mathrm{J}$ (with $j+1$ nominal, unordered outcomes), $i$ indexes the individuals, and the parameters $\beta^{8}$ reflect the impact of changes in $X$ on the probability that $Y=j$. To identify the model, we impose the normalization $\beta_{0}=$ 0 . The explanatory variables in $X$ consist of a set of human capital, individual specific characteristics, and labor market characteristics. These variables are the same for all choices, but their effects on the probability are allowed to differ for each outcome. They are expected to affect the individual's probability of being in a given state. We can predict the probability that an individual will choose one of the $\mathrm{J}$ states considered.

The log-odds ratios that an individual iwill choose alternative jover alternative $k$ are given by:

\footnotetext{
${ }^{7}$ This assumption about the independence of the disturbances leads to the Independence of Irrelevant Alternatives (IIA) property that characterizes the multinomial logit. It is a convenient but restrictive property. However, in cases where the outcome categories "can plausibly be assumed to be distinct and weighed independently in the eyes of each decision maker," a multinomial logit model can be safely used (McFadden (1973)).

${ }^{8}$ The parameters of the logit are not necessarily the marginal effects, but vary with the values of $X$. In essence, the estimated coefficient $b$ represents the change in log odds for a unit increase in the independent variable.
} 


$$
\ln \left[\frac{P_{j}}{P_{k}}\right]=X_{i}\left(\beta_{j}-\beta_{k}\right)
$$

Other "contrasts" of substantive interest can be computed by taking the difference between two of the known parameters as follows:

$$
\beta_{k, p \mid q}=\beta_{k, p \mid r}-\beta_{k, q \mid r}
$$

where outcome $r$ is the reference category. That is, we compare outcomes $p$ versus $q$ for attribute $k$. The model is solved with maximum likelihood estimation. Since likelihood equations are non-linear in the parameters $\beta$ an iterative algorithm is used for the maximization of the likelihood function. The resulting estimates, b, are asymptotically unbiased, consistent, normal, and asymptotically efficient. Moreover, the likelihood function is globally concave, ensuring the uniqueness of the Maximum Likelihood estimates (Amemiya 1985). The predicted probability values of being in a certain state are computed as follows:

$$
\begin{aligned}
& P_{0}=\frac{1}{1+\sum_{k=0}^{K-1} e^{b_{k} X}} \\
& P_{k}=P_{0} e^{b_{k} X}
\end{aligned}
$$

These probabilities can be calculated at the sample means or at given values of the $\mathrm{X}_{\mathrm{s}}$. The econometric method is discrete-time multinomial logistic regression for survival analysis, and nonrepeatable one-way transition events. That is, the event (emigration) occurs only at discrete time points and the transition from one discrete state to another occurs only once for each person. We model the risk of the event occurring at time $t$, given 
that the event did not occur before time t. By definition this is the ratio of the probability of the event occurring at time $t$ for individual $i$ divided by the probability of nonoccurence of the event prior to time t. In other words we model the probability that a migrant will return to hi or her country of origin over the probability that he or she will stay in the host country. In the following section we describe the database and lay the theoretical foundations for the underlying causes of the probability of emigration.

The standard human capital model of earnings is employed in this analysis. In addition, we allow for selectivity into the labor market because workers might differ from non-workers in unobservable ways. Because we have no information on characteristics of country of origin or the pool of workers from which immigrants are selected, we cannot model the decision to migrate to Germany jointly with earnings in Germany.

We differentiate between offered or market wages and observed wages. When the offered wage is greater that the reservation wage then the wage is observed. The offered wage equation has the following general specification:

$$
\ln W_{j}=\alpha_{1}+X_{1 j}^{\prime} \beta_{1}+\epsilon_{1 j}
$$

where $\mathrm{j}$ represents men or women immigrants and $\mathrm{X}_{1 j}$ is a vector of independent variables reflecting productivity, personal characteristics and labor market structure; the vector of

$$
L_{j}^{*}=\alpha_{2}+X_{2 j}^{\prime} \beta_{2}+\epsilon_{2 j}
$$

coefficients $\beta_{1}$ measures the effect of $X_{1 j}$ on earnings, controlling for everything else. The stochastic error term $\epsilon_{1 j}$ is assumed to be normally, identically, and independently distributed with zero mean and variance $\sigma_{\varepsilon}^{2}$, and $E\left[X_{1 j}^{\prime} \epsilon_{1 j}\right]=0$. 
The employment index function has the following general specification:

where

$$
L_{j}=\left(\begin{array}{cccc}
1 & \text { if } L_{j}^{*}>0 & \text { i.e. work } \\
0 & & \text { otherwise } &
\end{array}\right)
$$

The dichotomous variable $L_{j}$ stands for labor force participation status; this is equal to one if the individual works and zero if the individual does not work. The dependent variable $L_{j}^{*}$ is a latent variable that is positive when the wage is observed and indicates the propensity to work.

Normalizing so that the stochastic error term $e_{2 j}$ follows the standard normal distribution, the employment probability becomes:

$$
P\left(L_{j}=1\right)=\Phi\left(X_{2 j}^{\prime} \beta_{2}\right)
$$

The independent variables in the vector $X_{2 j}$ measure the wage offer and reservation wage, as well as some other factors not directly related to the worker's productivity; $\beta_{2}$ is a vector of the parameters to be estimated. ${ }^{9}$

The computed inverse Mill's ratio, $\lambda$, derived from the work model above, is included as an additional regressor in the earnings equation to adjust the mean of earnings for possible non-random selection of workers (Heckmann (1979)). The selectioncorrected earnings equation takes the following form:

$$
\ln W_{j}=\alpha_{1}+X_{1 j}^{\prime} \beta_{1}+c_{j} \lambda_{j}+v_{j}
$$

where $\ln W_{j}$ is the natural logarithm of gross weekly wages. The selectivity correction term is given by $\lambda_{j}=\frac{\phi\left(X_{2 j}^{\prime} \beta_{2}\right)}{\Phi\left(-X_{2 j}^{\prime} \beta_{2}\right)}$ and $c_{j}$ is the covariance between the error terms $\epsilon_{1 j}$ and $\epsilon_{2 j}$ divided by the standard error of $\epsilon_{2 j}$. Finally, $v_{j}$ is a stochastic error term that is

\footnotetext{
${ }^{9} \phi($.$) and \Phi($.$) are the pdf and cdf of the standard normal.$
} 
heteroscedastic and asymptotically uncorrelated with the variables in $\mathrm{X}_{1 \mathrm{j}}$. The estimates from this procedure possess the usual desirable asymptotic properties, such as unbiasedness, consistency, and efficiency.

\section{DATA AND MEASURES}

The empirical analysis is based on a nationally representative data set, the German Socioeconomic Panel (GSOEP). The GSOEP is an ongoing longitudinal database that started in 1984 in the former Federal Republic of Germany with a sample of about 12,000 respondents, 3,000 of whom were legal immigrants. The latter were those living in a household whose head was from Italy, Greece, Spain, Yugoslavia, or Turkey-the socalled guestworkers. The first wave covered the non-institutionalized population, but as the GSOEP follows and annually interviews all persons aged 16 or older, those who are institutionalized are retained in the study. Respondents were originally selected by a random walk procedure.

The GSOEP contains rich socioeconomic information on both native Germans and legal immigrants. Since the 1990 reunification, the sample had broadened to incorporate all Germans - West and East, and in 1996 the immigrant data base was expanded to include immigrants from other countries, especially eastern Europeans. The most important features of the GSOEP are that it oversamples guestworkers, and that it provides excellent information on their pre-immigration experiences and their degree of sociopolitical integration into the German community (SOEP Group 2001).

The GSOEP is especially suited for analyzing emigration probabilities because it has a good record of following individuals who move within Germany, and a good record of tracking immigrants who returned back to Germany after they had gone to their 
homeland (to serve in the military, for example). Temporary drop-outs or persons who could not be successfully interviewed in a given year are followed until there are two consecutive temporary drop-outs of all household members or a final refusal. The longitudinal development of the database is influenced by demographic and field- related factors. Specifically, attrition is related to mortality and migratory movements. It is also related to unsuccessful interviews and unsuccessful tracking of individuals throughout the survey. Overall, GSOEP has a relatively low attrition rate.

Our analysis is based on the first 14 waves of the GSOEP (1984-1997), although we use information on return migration from the subsequent three waves (1998-2000). For the purpose of this paper we focus on guestworkers only (as opposed to more recent migrants from the East), because they have been in the GSOEP since its inception. Even though since 1990 the GSOEP refers to the new united Germany, our guestworker sample is from the former Federal Republic. ${ }^{10}$ Each year we exclude immigrants on active military duty because military personnel follow different moving trajectories and may skew our emigration estimates (there were only a dozen such exclusions over the entire panel). Our sample contains all individuals over 16 years of age who were successfully interviewed in a given year.

Table 1 presents the yearly sample observations and the final longitudinal sample by gender. The longitudinal sample contains 4,613 guestworkers, of whom 2,382 are men and 2,231 are women. Out of these people, only 888 were in the panel for all 14 years (the balanced panel). Among the remaining 3,654 respondents (the unbalanced panel), some

\footnotetext{
${ }^{10}$ Guestworkers did not move to the new states after the reunification but have remained concentrated in the former West German territory, exclusively.
} 
started in the panel and then dropped out temporarily or permanently; some entered the panel in later waves and left or stayed; and some were repeat entrants. As of the year 2000, the GSOEP documents 73 guestworkers who have died and 817 who moved abroad, the emigrants of our sample; they constitute 17.71 percent of guestworkers.

\section{TABLE 1 ABOUT HERE}

To implement the event history analysis we restructured the GSOEP data into "person-years," which became the effective units of analysis. A person-year is a one-year fraction of a person's life during which the event in question (emigration) may or may not occur. Each yearly fraction of a person's life is treated as a distinct observation. The person-year file contains information about the occurrence or nonoccurence of the emigration event, as well as the values of relevant independent variables (with or without temporal variation); it is the life history of each person.

By definition, all immigrants are at risk of returning to their home country from the moment they arrive in Germany. We assume that immigrants enter the population at risk at age 16 or the point of entry into the GSOEP and that they remain at risk until the time of emigration or censoring. ${ }^{11}$ It is not necessary that every person experience the event. We also assume that right-censoring is random so that the time between the beginning and end of an observation is independent of the timing of events (Massey 1987). The final person-year file had 33,493 observations, representing detailed longitudinal histories of immigrants' experiences and behavior from the moment immigrants entered the sample until emigration, death, or the final survey date.

\footnotetext{
${ }^{11}$ In the case of right-censored observations we include information about their survival up to the time of censoring without making any assumptions about the timing of the event's occurrence in the future (Yamaguchi (1991)).
} 
Variables may either be fixed or time-varying. Those variables that change from year to year include age, years since migration, education in the host country, and weekly wages. Those variables referring to fixed characteristics such as gender and education before migration remain constant over person-years.

We define the guestworker population in the GSOEP in any year after 1984 by the following identity:

$$
G \equiv I-A+N
$$

where $G$ is the guestworker population, $I$ is the initial guestworker population in 1984, $A$ is the sample attrition, and $N$ is the new guestworkers who entered the sample after 1984. We further define sample attrition as:

$$
A=D+E+L
$$

where $D$ is the sample attrition due to mortality, $E$ is attrition due to emigration, and $L$ is attrition due to unsuccessful tracking or interviewing of individuals. All components of equation 13 are known in the GSOEP. In our analysis, therefore, we adjust for mortality and classify as emigrants those who are documented by the GSOEP as having moved abroad.

The main idea of employing a multinomial logit model is that we are able to distinguish between the immigrants who go back to their home country, those who choose to stay in Germany, and those who are lost to follow-up. Our dependent variable $(E)$ is a categorical variable that takes the value of zero if the individual stays in Germany, the value of one if an individual has emigrated, and the value of two if we are uncertain about the individual's whereabouts. The resulting emigration rate is about eighteen percent. We attempt to identify the underlying causes of return migration and its 
consequences on earnings assimilation by grouping the potential determinants of emigration under several conceptual headings. Table 2 presents this classification along with the predicted effects. We first consider human capital and how it influences the individuals' probability to emigrate. According to the neoclassical economic theory, the young, the healthy, and the more educated are more likely to migrate. ${ }^{12}$ Here we distinguish between experience, education, and skills acquired in sending versus receiving countries. Immigrants who invest more in the host country will be less likely to emigrate. By investment in the host country we mean investment in skills, such as education and training, and in learning the language.

To capture non linearities of formal schooling in Germany ${ }^{13}$ we created five dummy variables following the GSOEP questionnaire. They indicate investment in human capital, which may contribute to better job opportunities and higher earnings in Germany. We expect that immigrants who went to school in Germany will be less likely to emigrate. Obtaining no degree in Germany is the reference category. Vocational training is a unique feature of Germany's educational system and an important part of formal education for non-university goers who want to access skilled jobs. It includes trade/agricultural apprenticeship, business school, technical college, and college or university education. Our measure of human capital includes the effect of training in addition to formal education. Because vocational training is more country specific, we expect that immigrants with vocational training in Germany will be less likely to emigrate.

\footnotetext{
${ }^{12} \mathrm{~A}$ move is an investment in human capital that is justified according to a cost-benefit analysis (Sjastaad (1962)). The rationale is that younger immigrants will be able to reap the rewards of their investment.

${ }^{13}$ This is also important because it reflects the age at entry effect. The younger the immigrants arrive in the host country, the lower their emigration rates will be.
} 


\section{TABLE 2 ABOUT HERE}

The literature on assimilation has established that speaking the host country's language fluently facilitates the transfer of skills and the acquisition of human capital, and may also reduce employer discrimination. German language proficiency is important in determining job prospects, occupational advancement, and earnings, and reflects the ease with which guestworkers are assimilated. The dummy variable speaking German fluently is constructed from a self-assessed skill question. We expect language fluency to decrease the probability to emigrate. Education acquired in the country of origin, is entered as a continuous variable in the estimation; it includes both formal schooling and vocational training. The average years of schooling and vocational training for all five groups of guestworkers were assigned to this variable (Constant (1998)). We expect that immigrants who went to school in their home country will be more likely to return to their home country. They will not face the problems of the nontransferability of credentials and will have less difficulty finding a job after remigration.

Years since migration (YSM) is a key variable that captures investment in human and social capital in the host country as well as other intangibles, such as a bond or attachment with the new country and making new roots. Besides measuring assimilation, additional years of residence in Germany also increase the probability of being employed in Germany. Finally, this variable captures the estrangement or distancing of immigrants from their home country. We expect to find that the propensity to emigrate is convex in YSM, and that additional years of residence in Germany constitute a strong deterrent to return migration. We construct this variable from the year of immigration and the current wave. For those guestworkers who are born in Germany we subtract the birth year from 
the current wave.

The second variable grouping refers to work effort. It is measured in terms of three categorical variables: i) part time employment (working less that 35 hours per week), ii) in training or apprenticeship, and iii) full time employment, which is the reference group. The third set of determinants of return migration is the attachment to employment. Here we consider three groups of workers: those who work irregularly; those who are officially registered as unemployed; and those who are out of the labor force. All these variables capture the degree to which an immigrant participates in paid labor force in Germany or is living off of welfare. Immigrants who are attached in the German labor market will be less likely to return.

The fourth category of determinants we label socioeconomic achievement. Wages and occupational prestige are the two indicators of socioeconomic achievement. According to the theory of emigration the effect of this variable on return migration is ambiguous. Economically successful immigrants, who feel that their mission has been accomplished abroad might decide to return home. In this case, higher earnings increase the probability to return. On the other hand, return migrants may be those who were unable to 'make' it in the new country and are disappointed about their migrant career. Lower earnings may, thus, increase the probability of emigration, as well. We measure occupational prestige using the Treiman International Occupational Prestige Scale (Treiman 1977). This variable captures social standing, power, respect, life-style, and life chances. In a traditional society like Germany job hierarchies are paramount. The higher the prestige score, the more immigrants are successfully integrated, and the less likely they are to emigrate.

Attachments to Germany is the next heading of variables. These attachments could 
be social (having family, spouse, children, or relatives in Germany, and professional contacts), economic (owning property, house, or business), psychological (having a feeling of comfort in Germany, being at ease, and feeling at home), or political (become naturalized citizen). The probability of return is negatively related to all of these variables. Being born in Germany mainly reflects the age at entry effect. Given the idiosyncracies of the German naturalization law this variable does not necessarily indicate German citizenship but can be thought of as a dimension of social stratification. ${ }^{14}$ Guestworkers who are German born will be more assimilated and feel that Germany is their home. The German born will, therefore, have a lower probability of emigration. Moreover, German citizenship may open the door to jobs and opportunities not available to legal immigrants.

In contrast, if immigrants have kept strong ties with the country of origin they are more likely to return home. We identify as attachments to country of origin the immigrant spouse and children living abroad, and whether the immigrant sent remittances abroad. We believe that remittances capture differences in migration intent. Remittances indicate two effects. First, that immigrants keep strong ties with family and friends in their home country. Therefore, they remit either to repay a debt, to pay for a sister's dowery, for the parents' health care, for financial support of close relatives, or to fulfill previous financial arrangements. Second, immigrants remit for their own financial benefit in the home country. That is, to help build their own house, to buy a taxi, start a new business when they return, to be able to afford more capital goods, or invest in new ventures. We expect that those who remit will have a higher probability of returning.

\footnotetext{
${ }^{14}$ Because our analysis is based on the legal guestworker population this variable does not reflect legal status.
} 
The following are additional control variables. To capture any non-linear effects of age on return migration, we constructed the following 4 dummy variables: i) individuals aged 19-24, ii) individuals aged 25-64, iii) individuals over 65 years old, and iv) individuals aged 16-18 who serve as the reference group. The young and the old (after retirement) will have the higher probability of return. We expect the younger immigrants aged 19-24 to be more likely to emigrate. This is the age range where immigrant children might go to their "native" countries to acquire university education and where men must join the army for their compulsory service. At prime working age (25-64) emigration rates drop to a minimum, and increase again as one becomes older and retires from the labor market. Moreover, we constructed 10 dummy variables for geographic location, following the GSOEP classification of the former western federal states and the city-states of Berlin and Hamburg. ${ }^{15}$ These variables refer to contextual factors, and capture the job opportunities, the regional unemployment rate, the population density of place of residence, and the amenities and disamenities of a region. We chose Berlin, the capital, as the omitted location because Berlin is a major absorption center for immigrants.

The immigrants nationality captures the macroeconomic conditions and the political environment of the home countries. Nationality also captures characteristics, such as the political regime, and income inequality of the country of origin. To investigate the hypothesis that national origin is very important in determining the type of selection that characterizes the migrant flow, the speed of assimilation, as well as the emigration rates, we included three additional dummy variables. Turk and $\underline{\text { Yugo }}$ are two dummies indicating

\footnotetext{
${ }^{15}$ This geographic classification is analogous to the SMSAs in the United States. SMSA structures do not exist in European countries.
} 
immigrants from Turkey and the former Yugoslavia respectively. We expect guestworkers from these nationalities to want to stay in Germany, given the institutional constraints that they face (Turks) and the political upheaval they face (Yugoslavs) if they were to return to their countries of origin. The reference category is $\underline{E U}$ and stands for the rest of guestworker nationalities that are members of the European Union (Italians, Greeks, and Spaniards) and anyone else. ${ }^{16}$ Finally, we included 13 more dummy variables for the period effects. Each dummy variable represents a year in the panel; the reference year is 1984. The general treatment of the variables employed in this analysis is that if some control variables had missing values we replaced the missing value with the mean value and flagged them with dummy variables indicating missing values (Lillard and Willis (1994)).

\section{CHARACTERISTICS OF THE SAMPLE POPULATION}

Table 3 presents the selected human capital and labor market characteristics of our sample populations in both 1984 (the first year of the study) and 1995. We chose 1995 because many emigrants are still in the sample, and we can look at the immigrant progress within a decade. The first two Columns refer to all guestworker men (except Turks), and the next two Columns refer to all guestworker women (except Turks) in the respective cross-sections.

\section{TABLE 3 ABOUT HERE}

Overall, these summary statistics show that from 1984 to 1995 , guestworkers as a group, have somewhat improved their standing in Germany with regards to both human

\footnotetext{
${ }^{16} \mathrm{EU}$ members have a 5 year residence permit, which is automatically renewable, and do not need a working permit. They face no political restrictions or visa requirements. In 1984 when the GSOEP study began only Italians had unrestricted entry and exit as members of the EU. By 1988 Greeks were also EU members and by 1990 Spaniards were EU members as well.
} 
capital and socioeconomics. Nonetheless, after a quarter century in Germany they hardly identify themselves as Germans; only 5 percent of them feel as Germans, with women feeling more German than men. From Columns 1 and 2 we see that male guestworkers have, on average, higher prestige scores, and earn more Deutsche Marks per week than women guestworkers (Columns 3 and 4). Men also work more hours per week than women both in 1984 and $1995 .{ }^{17}$ Clearly, immigrant men and women in Germany fit into the traditional German labor roles whereby women do not participate in the labor market and if they do they are only in part time employment. Further, the immigrant men's labor force participation (LFP) rates have decreased in 1995, and the percentage of the not employed has increased in 1995. In contrast, women in 1995 have increased their LFP rates and decreased their non employment rates. Although men as a group have higher prestige scores, earn more Deutsche Marks than women, have higher labor force participation (LFP) rates, and less of them are not employed, it is the women who have shown a remarkable improvement in trying to close the gap.

Men and women guestworkers are indistinguishable with regards to their time in Germany, but men are, on average, older than women and have more years of education before migration. Although the average years of schooling in the home country have declined for the guestworkers as a whole, this does not indicate any decline in the "quality" of guestworkers. Instead this decline is due to the permanency of guestworkers in Germany. That is, the second generation immigrants are schooled in Germany and, thus, have no education in their parents home country. Both men and women have comparable

\footnotetext{
${ }^{17}$ Both men and women work fewer hours per week in the 1990s. We believe that this rather reflects the general trend in Europe.
} 
German education levels and within this decade a larger percentage of them obtain a German degree. Yet, only 1 percent of men (2 percent for women) finishes the academic high school (Abitur) which gives access to higher education. With regards to vocational training in Germany, an integral part of the German educational system, we see that a larger percentage of both men than women have obtained vocational training in Germany in 1995. According to their self-assessment more men speak German fluently in 1984 but by 1995 more women speak German fluently. It is interesting to note that the percentage of guestworkers who speak German fluently has more than doubled in 10 years. We suspect that this is due mostly to the second generation immigrants who are born and schooled in Germany.

The majority of both men and women guestworkers are married and live with their spouses in Germany. It is only a very small percentage of them who have a spouse in the home country and this is true more for men in 1984. It is interesting to note that this percentage has dropped by more than half in the decade under consideration. Similarly, the percentage of the average male guestworker who has children in the home country fell from 11 to 2 percent in a decade (and from 9 to 1 percent for the average female). These statistics confirm the de facto permanency of the guestworker population in Germany. In particular, the percentage of guestworkers who are born in Germany increased from 5 percent in 1984 to 30 percent in 1995 for men and from 11 to 36 percent for women. Another striking change in the guestworker population is that by 199526 percent of men and 33 percent of women are German citizens (as opposed to 4 and 6 percent in 1984), and about 17 percent of guestworkers own their dwelling in Germany by 1995 (as opposed to 7 percent in 1984). 
The national origin mix among immigrants in Germany is such that Turks are the majority (more than 30 percent) in both 1984 and 1995. The percentage of immigrants from the former Yugoslavia has slightly increased in 1995, and in sharp contrast, there is a pronounced compositional shift with respect to EU nationals. The percentage of EU nationals in 1995 has dropped by 51 percent for men and 65 percent for women. Lastly, these summary statistics show that a larger percentage of men than women remit, and although the percentage of guestworkers who remit in 1995 has dropped, a quarter of them still remits money funds to the home country. In sum, the summary statistics from Table 3 portray an immigrant population that has settled in Germany permanently. On average, therefore, we can argue that guestworkers choose to stay in Germany and their "sojourn" is permanent, an oxymoron of their guestworker title.

In Table 4 we present the characteristics of the largest immigrant population in Germany and in our sample, the Turks. Compared to the rest of guestworkers in Table 3, Turks, on average, earn below average wages in both 1984 and 1995, have below average prestige scores, and work below the overall average hours. ${ }^{18}$ Turks are also younger and have less years in Germany than the rest of guestworkers, as expected from the bilateral treaties. Overall, their educational characteristics resemble the total foreign population except that their fluency in German remains at a very low level. From the rest of their characteristics it is evident that the Turkish population is living in Germany permanently. For example, in 1995, more than 80 percent of them live with their spouses in Germany, and more than 60 percent have their children with them in Germany, while 10

\footnotetext{
${ }^{18}$ From the supportive Tables A3.1 and A3.2 it is also clear that Turks earn the lowest wages from all other nationalities.
} 
percent of them own their dwelling in Germany. On the other hand, only 4 percent of Turks are born in Germany and an even lower percentage of them (2 percent) feel German. Lastly, their tendency to remit and maintain ties with the motherland has decreased by 1995 but it still remains at a higher level than the rest of the guestworker population.

\section{TABLE 4 ABOUT HERE}

In sum, three important trends are evident from this table. First, immigrants in Germany exhibit the characteristics of permanent migrants and as such they have ameliorated their economic and educational standing. Nonetheless, in the decade under consideration, their Treiman prestige scores remain low indicating unskilled or semiskilled workers. Second, women have performed remarkably better than men in the labor market, trying to close the gap with men, and third, immigrants in Germany still remain permanent foreigners both in their own eyes and in the eyes of the German law.

\section{DETERMINANTS OF EMIGRATION}

Table 5 presents the results of the survival analysis of emigration probabilities. For this estimation we follow the updated GSOEP 2000 documentation on the immigrants who left Germany to move abroad. There are 817 guestworkers documented to have left Germany permanently over the 14 year period of our study. The first two columns of Table 5 refer to the choice outcome "emigrate versus stay in Germany" and the last two columns refer to the choice outcome "left the sample versus stay in Germany." The coefficient estimates of the log odds (B) of emigrating versus staying in Germany are in columns (1) and (3), and the standard errors (SE) are in columns (2) and (4). Overall, this Table shows that the return immigrants are a self-selected group of immigrants with regards to some socioeconomic facets. Surprisingly, return migrants from Germany do not appear to be 
selected with respect to human capital acquired in Germany, except fluency in the German language. That is, the guestworkers who speak German fluently have a lower probability of returning to their home country. On the other hand, as expected, the odds of returning are higher for those guestworkers who have had some years of schooling before migration.

\section{TABLE 5 ABOUT HERE}

Further, we find that the odds of returning decrease, though at an increasing rate, with additional years of residence in Germany but the coefficients are only at the verge of significance. This result is similar to Borjas (1989) who finds a convex pattern of the yearssince-migration variable, and to Dustmann (1993). Based on equation 6 and the results of Table 5 we calculated the predicted value of the probabilities of emigration, of staying in Germany, and of being lost to follow-up for the average guestworker. In Figure 1 we plot the probability of emigration ${ }^{19}$ and juxtapose it with the probability to stay in Germany as a function of time since first arrival in Germany, holding everything else constant. Accordingly, the probability of returning to the home country (red curve) as one accumulates years of residence in Germany is very mildly convex and hovers around zero. This probability is higher for the most recent immigrants (those with less than ten years of residence in Germany), and it increases after 50 years of residence in Germany. Figure 1 shows that the curve tracing the probability of staying in Germany (blue curve) is also convex. Clearly, in the beginning of the first move, each additional year of living in Germany has a slightly negative influence on the probability of staying in Germany. After 20 years in Germany, the probability of staying in Germany increases at an increasing rate and approaches one.

\footnotetext{
${ }^{19}$ All Figures have been calculated at the mean value of the rest of the regressors.
} 


\section{FIGURE 1 ABOUT HERE}

The rest of the coefficients in Table 5 show that return migration is highly selective with respect to attachment to employment in Germany. Those immigrants who have week ties to the labor force, that is, immigrants who are registered as unemployed, or those who are not employed, have a significantly higher probability of returning to their home country versus staying in Germany compared to those who work full time. Return migrants from Germany do not appear to be selected with respect to wages, while they are negatively selected with respect to occupational achievement or prestige of the job. Guestworkers with higher prestige scores, who rank higher in the occupational hierarchy have a lower their probability of return.

As predicted in the theoretical section, we find that the guestworkers who have their spouses in Germany, who have become German citizens, and who "feel German" are less likely to return. On the other hand, those guestworkers who kept strong ties with the country of origin - either by leaving their family behind, or by remitting - are more likely to return.

Among the rest of the control variables, we find a strong effect of old age on the probability of return. Namely, immigrants over 65 years of age have a higher probability of return, indicating a link between return migration and retirement. With regards to gender, we are not able to confirm a significant association between gender and return migration. In fact, when we disaggregated by gender the general portrait of the selfselective character of return migration among immigrants in Table 5 is replicated by Tables

A5.1 and A5.2 of the Appendix for men and women respectively. With the exception of prestige - which matters for women only - and the exception of age - which matters for men 
only - the results are astonishingly the same. Figures 6 and 7 trace the probabilities of staying in Germany, of being lost to follow-up, and to emigrating for men and women respectively. For both men and women, the probabilities of emigration are rather flat and hovering around zero. Overall, the calculated probabilities are the same, although the curves for women show a more pronounced curvature.

The next group of control variables pertains to the heterogeneity of immigrants with respect to their nationality. Emigration rates vary by nationality with the European Union members having the highest probability of return. Viewed differently, these coefficients show that Turks, and guestworkers from the ex-Yugoslavia have the lowest chances of going back to their countries of origin. Controlling for everything else, and compared to those residing in Berlin, guestworkers residing in every other state are more likely to return to their home country. Lastly, from the coefficients of the period effects we see that the probability of emigration decreases significantly every subsequent year after 1984 .

In sum, the model has good predictive power as indicated by the Log Likelihood and the $\mathrm{X}^{2}$ test. In Tables A6.1 and A6.2 we present the results of the event history probability of return from a plain logit for all guestworkers and for men and women separately. The results of this exercise are identical to the multinomial results. The basic conclusions from this analysis are that the migrants who return home are selected mainly in terms of their social and economic attachments to Germany and their sending nations. Those with weak employment attachment in Germany are more likely to return; those with strong social attachments to Germany are more likely to stay; and those with strong social and economic links to countries of origin are more likely to leave. Human capital, and earnings are not significant determinants of the probability to return home, once we control for 
employment and social, and psychological attachments.

In the next section we address the question of selection bias results in cross sectional studies on immigrant earnings assimilation.

\section{ADJUSTING FOR SELECTIVE EMIGRATION}

To test the hypothesis that cross-sectional earnings estimates on immigrant assimilation suffer from selective emigration bias we estimated human capital earnings regressions for several cross-sections in our panel. First, we estimated plain earnings regressions and second, we reestimated the models adjusting for labor force participation bias following the Heckman two-stage technique. ${ }^{20}$ In the first approach, we estimated Mincerian earnings regressions for the entire guestworker population in the GSOEP in a particular year. Then, we estimated Mincerian earnings regressions on a restricted population that same year by omitting from the entire guestworker population the emigrants (traced from the subsequent years). In this analysis the dependent variable is the natural logarithm of weekly wages. The explanatory variables include human capital variables, assimilation variables, family status variables, and labor market characteristics.

The estimated results based on positive wages of the first wave (1984) are presented in Table 6. The total number of guestworkers who left Germany in 1984 is 677 (or 420 accounting only for the workers with positive wages). Based on the workers with positive wages, this restricted sample is reduced to 1619 observations. The first three columns of Table 5 present the estimated earnings results on the entire guestworker population while the last three columns present the estimated earnings results on the guestworker population who did not emigrate. T-ratios are underneath the coefficients in

\footnotetext{
${ }^{20} \mathrm{We}$ also experimented with a bivariate probit with selection, adjusting the wages for both remigration and labor force participation. We obtained the same results.
} 
parentheses, and the asterisk indicates a significance level of five per cent in a two-tailed test. In Columns 1 and 4 we present the results of the simple human capital model, in Columns 2 and 5 we present the results of the model augmented with family characteristics, and in Columns 3 and 6 we add labor market characteristics and nationality variables in the model. ${ }^{21}$

All specifications of Table 6 show similar results. Overall, the wages of guestworkers are concave in age. Wages increase with age at a decreasing rate, they reach a maximum around the age of 42 for the entire immigrant population in 1984 and around the age of 41 for the restricted population in 1984, and start decreasing thereafter. In Figure 2 we plotted the estimated age-earnings profile of guestworkers, calculated at the average value of all the other determinants, from age 16 to 60 . The blue curve represents the entire sample in 1984 in Germany based on the estimated results of Column 3. The red curve represents the estimated age-earnings profile produced from the restricted sample (Column 6). Amazingly, we find that these two profiles are identical and they overlap one another for a good part of the working lives of the guestworkers. Only at the two tails is there a small gap between the two samples. This indicates that at both at younger ages (less than twenty) and at older ages (more than fifty) the emigrants have higher wages than the rest of the immigrant population.

\section{FIGURE 2 ABOUT HERE}

We are surprised to find that the coefficients on the years since migration variable have perverse signs, although other researchers have found the same result (Borjas 1987). At first sight, our wage estimation for 1984 shows that the wages of guestworkers

\footnotetext{
${ }^{21}$ Just for comparison we present the results of the parallel analysis for the $12^{\text {th }}$ wave $(1995)$ in the Appendix, Tables A7, A8, and A9. Results on other cross sections are available upon request.
} 
decrease with time in Germany. ${ }^{22}$ This does not mean that there is no wage assimilation. In Figure 3 we plot the YSM-Earnings profiles of guestworkers in Germany in 1984 based on the results of Column 3 in Table 6 . The resultant YSM-earnings profiles are plotted at the average level of all other characteristics for the entire population (blue curve) and the restricted set (red curve). This Figure clearly shows the earnings disadvantage of the guestworkers in the beginning of their immigrant careers and their improvement after the first fifteen years of residing in Germany. Specifically, the earnings of immigrants are rather flat during the first 15 to 19 years in Germany but they increase at an increasing rate thereafter. Similar to Figure 2, we find that there is no discernable difference between the wages of the entire guestworker population and the restricted guestworker population.

\section{FIGURE 3 ABOUT HERE}

From the rest of the coefficients in Table 6, we see that there are significant gender differences in wages with men earning about 38 percent more than women both in the entire population and the restricted set. From the human capital acquired in Germany those with a high school diploma earn about $25 \%$ more than those who have no degree in Germany. Vocational training is also a significant determinant of wages but has a perverse sign. The guestworkers who have vocational training in Germany earn about 8 percent less that those who do not have any vocational training while each additional year of education before migration significantly increases the wages of guestworkers by about 2 percent. As expected, speaking the German language fluently is rewarded in the labor

\footnotetext{
${ }^{22}$ The corresponding analysis for 1995 shows that the YSM coefficients are only mildly quadratic and not significantly different from zero. Figure 9 portrays these profiles. Clearly, the two curves are almost flat and lie on top of each other. These profiles are consistent with previous research on assimilation that has found that the wages of guestworkers in Germany do not increase significantly with additional years of residence in Germany (Constant 1998).
} 
market but when we control for hours of work and occupational prestige, the benefits from German fluency are wiped out. From the coefficients on the family variables we see that there is a wage premium of about 15 percent for married individuals but, on the other hand, there is a penalty for those guestworkers who have kids.

In Columns 3 and 6 we control for labor market characteristics. We see that the wages of guestworkers are significantly tied to their hours of work, reflecting the fact that guestworkers are in the lower tier of the labor market. Wages increase with each additional hour of work by 1 percent. Wages also increase with the type of job immigrants hold. Specifically, the higher the Treiman prestige score (or the more they climb up the socioeconomic ladder) the higher their earnings are. Lastly, we find that both Turks and German citizens have lower wages than the immigrants from the EU. The astonishing conclusion from this Table is that the wage profiles of the entire and the restricted population are the same. Although there is selection in return migration (documented in Table 5 above) this selection does not affect the wages. The 420 guestworkers who left Germany in 1984 have not affected the wage distribution of the guestworkers who stayed in Germany. This could be due to the narrower income distribution in Germany and to the small dispersion of the guestworker wages.

In a second approach, we reestimated earnings regressions for the entire guestworker population in the GSOEP in a particular year and for the restricted population that same year by omitting from the entire guestworker population the emigrants while we corrected for selectivity into the labor market. The estimated results from equation 10 are presented in Table 7 while the results of the earnings assimilation analysis adjusting for the non randomness of workers (equation 11) are presented in Table 8. Column 1 of Table 
7 presents the results of the labor force participation probability for the entire population and Column 2 presents the results of the restricted population in 1984. Overall, the results are the same for both populations and conform with the human capital model. The probability of employment increases with age and additional years of residence in Germany, and is higher for men. The guestworkers who have some basic education, vocational training in Germany, and some schooling before migration are more likely to participate in the labor market. On the other hand, those immigrants who are married and have young kids in the house are less likely to work. The coefficients on the remittances variable show that the guestworkers who remit have a very high probability to work. Controlling for everything else, Turks have the lowest probability of employment in Germany, compared to EU nationals. In sum, the probit estimation results are the same for both the entire guestworker population in 1984 and for the restricted population.

In Table 8 we present the wage estimation results adjusted for employment bias and heteroscedasticity. Following the same format, the first column estimates are based on the entire guestworker population in 1984 with positive wages, and the second column estimates are based on the restricted set of guestworkers who stayed in Germany. The estimated results across all specifications are stunningly similar to Table 6. On average, for both populations we find that wages are concave in age, and convex in YSM, and they do not significantly depend on schooling in Germany, nor fluency in German. Instead, wages increase with years of schooling before migration and decrease with vocational training. Table 8 also confirms the gender disparity in wages. Although there is a decrease in the gender gap compared to Table 6, guestworker men still earn about 24 percent more that women. From this wage analysis in 1984 we find that the wages of guestworkers 
increase with additional hours of work, and with higher Treiman prestige scores. As before, all non-EU nationals are penalized in the market, even those who have legally become German citizens. The selection term $\lambda$ is negative and significant only for the entire population. This indicates that the guestworkers are not randomly selected into the labor market; instead, unobserved variables, correlated with employment and earnings, strongly select guestworkers into lower paying jobs. Further, this indicates that immigrant workers have lower wage offers than non-workers with similar measured characteristics.

In Figure 4 we plotted the age-earnings profile of the entire guestworker population (blue curve) and juxtaposed it to the age-earnings profile of the guestworker population who stayed in Germany in 1984 (red curve). This picture is identical to figure 2. With the exception of the small gap between the curves for younger and older immigrants, the ageearnings profiles of guestworkers are the same for both the entire and the restricted population. Anytime the blue curve, representing all guestworkers in Germany, lies above the red curve, representing the guestworkers who stayed in Germany, this indicates that the emigrants are positively selected with respect to wages or that they have higher wages than the non-emigrants.

\section{FIGURE 4 ABOUT HERE}

In Figure 5 we traced the YSM-earnings profiles for the entire and the restricted immigrant population in 1984. Figure 5 shows only a hairline gap between the two populations. This hairline difference does not justify any significant wage difference nor a selection bias. Figure 5 shows a very similar pattern to Figure 3.

FIGURE 5 ABOUT HERE

The most important result from the cross sectional earnings regression analysis is 
that the coefficients of both the restricted and the entire guestworker population are the same. This is as expected from the event history analysis, whereby emigrants in Germany are not selected with respect to wages. In sum, similar to Lindstrom and Massey's (1994) study, we were not able to confirm that selective emigration significantly biases crosssectional earnings assimilation results. ${ }^{23}$

\section{CONCLUSION}

In this paper we addressed the question of selective emigration and how it affects cross-sectional earnings results. Using the German panel data during the period 19841997 we estimated multinomial logit models to predict the probability of emigration as a function of human capital, time in Germany, demographic, and labor market characteristics. We began by estimating a multinomial logit model that followed migrants from their point of entry into the GSOEP up to their emigration or the final survey date, using the updated code for permanent emigration included on the GSOEP file to indicate a departure. This analysis showed that return migrants were not very selected with respect to human capital characteristics or economic achievements, but were highly associated to various social and economic attachments to Germany and countries of origin. While schooling in the home country significantly increased the odds of returning, neither education in Germany, German vocational training, or earnings in Germany, significantly predicted the likelihood of return migration.

In contrast, fluency in German and higher occupational prestige significantly decreased the odds of returning. Further, the decision to emigrate was strongly determined by the existence of social ties in Germany (presence of spouse and children), political ties

\footnotetext{
${ }^{23}$ When we replicated the analysis for other cross-sections we also obtained the same results.
} 
(being a German citizen), and psychological ties (feeling German). Likewise, return migration was strongly influenced by tight bonds to the home country either social (spouse or children abroad) or economic (remitting money abroad). Emigration was not selective of sex, but was selective with respect to nationality. Migrants from Turkey and the former Yugoslavia were least likely to return back to their home countries while those from the EU were most likely to do so.

Our event history analysis showed that an essential consideration for the decision to return is being employed in Germany. In fact, having a job in Germany is far more important than the remuneration of the job. Guestworkers are more likely to return home when they lose access to German jobs. Our results show that immigrants in Germany migrated for employment and continue to stay so long as they have employment in Germany. For the average immigrant, the probability of return is very low - close to zero and this is irrespective of gender.

Finally, from a standard human capital earnings regression cross-sectional exercises we could not confirm any serious selection bias with respect to emigration. This conclusion is echoed in all cross-sectional analyses, even after we adjusted for employment selection. In congruence with previous studies, we found that cross sectional earnings results do not suffer form selection biases with respect to emigration. In sum, the wage regressions showed that there are significant wage disparities between men and women with men earning close to 38 percent more than women. Vocational training acquired in Germany as well as education acquired in the home country were the only facets of human capital that determine wages. Overall, the wages of immigrants increase with age at a decreasing rate; they also increase with YSM but only after the first fifteen 
years of residence in Germany. As is indicative of laborers in the second tier of the labor market, hours of work significantly determine the wages of immigrants. Finally, nationality matters for the wages of immigrants in Germany, with EU nationals earning more than any other group. 
TABLE 1. YEARLY OBSERVATIONS BY GENDER

\begin{tabular}{|c|c|c|c|c|}
\hline WAVE & YEAR & $\begin{array}{c}\text { MALES } \\
(1)\end{array}$ & $\begin{array}{c}\text { FEMALES } \\
(2) \\
\end{array}$ & $\begin{array}{c}\text { TOTAL } \\
(3) \\
\end{array}$ \\
\hline 1 & 1984 & 1592 & 1418 & 3010 \\
\hline 2 & 1985 & 1375 & 1226 & 2601 \\
\hline 3 & 1986 & 1349 & 1180 & 2529 \\
\hline 4 & 1987 & 1345 & 1197 & 2542 \\
\hline 5 & 1988 & 1275 & 1160 & 2435 \\
\hline 6 & 1989 & 1237 & 1167 & 2404 \\
\hline 7 & 1990 & 1242 & 1145 & 2387 \\
\hline 8 & 1991 & 1241 & 1148 & 2389 \\
\hline 9 & 1992 & 1224 & 1148 & 2372 \\
\hline 10 & 1993 & 1220 & 1139 & 2359 \\
\hline 11 & 1994 & 1158 & 1110 & 2268 \\
\hline 12 & 1995 & 1089 & 1053 & 2142 \\
\hline 13 & 1996 & 1043 & 1018 & 2061 \\
\hline 14 & 1997 & 1015 & 979 & 1994 \\
\hline \multicolumn{2}{|c|}{ All 14 Waves (individuals) } & 2382 & 2231 & 4613 \\
\hline \multicolumn{2}{|c|}{ Person Year Observations } & 17405 & 16088 & 33493 \\
\hline \multicolumn{2}{|c|}{ Emigrants } & & $817(18 \%)$ & \\
\hline
\end{tabular}

Source: Own calculations from GSOEP 1984-1997 
TABLE 2. THEORETICAL VARIABLES AND THEIR DEFINITIONS IN MODELS PREDICTING THE RETURN MIGRATION OF IMMIGRANTS FROM GERMANY

Predicted

\begin{tabular}{|c|c|c|}
\hline Definition & Direction of Effect & \\
\hline \multicolumn{3}{|l|}{ Human Capital } \\
\hline Home Country Schooling & Years of schooling or vocational training at home & + \\
\hline Time Since Migration & Years since migration & - \\
\hline \multicolumn{3}{|l|}{ German Education } \\
\hline No Degree & Reference & \\
\hline Primary-Secondary & Attended primary or secondary school in Germany & - \\
\hline Technical & Finished technical school in Germany & - \\
\hline Abitur & Finished academic high school in Germany & - \\
\hline Other & Completed other degree in Germany & - \\
\hline German Vocational Training & Obtained vocational training in Germany & - \\
\hline Fluent in German & Speaks German fluently & - \\
\hline \multicolumn{3}{|l|}{ Work Effort } \\
\hline Full Time & Reference (works 35+ hours per week) & \\
\hline Part Time & Respondent works part time & + \\
\hline In Training & Respondent in training & + \\
\hline \multicolumn{3}{|l|}{ Attachment to Employment } \\
\hline Marginally Employed & Respondent works irregularly or is minimally employed & + \\
\hline Unemployed & Respondent is registered as unemployed & + \\
\hline Not Employed & Respondent not working or looking for work & + \\
\hline \multicolumn{3}{|l|}{ Socioeconomic Achievement } \\
\hline Earnings & Weekly gross earnings in $100 \mathrm{DM}$ & 0 \\
\hline Prestige & Value on Treiman International Occupational Scale & - \\
\hline \multicolumn{3}{|l|}{ Attachment to Germany } \\
\hline Spouse in Germany & Married with spouse in Germany & - \\
\hline Children in Germany & Children $<16$ in household & - \\
\hline German Born & Respondent born in Germany or entered before 1949 & - \\
\hline Own Home & Respondent owns home in Germany & - \\
\hline Feel German & Respondent feels "totally German" & - \\
\hline German Citizen & Respondent has German citizenship & - \\
\hline \multicolumn{3}{|l|}{ Attachment to Origin } \\
\hline Spouse in Home Country & Married with spouse outside Germany & + \\
\hline Children in Home Country & Children $<18$ in home country & + \\
\hline Remitted & Respondent sent money to friends or relatives at home & + \\
\hline
\end{tabular}


TABLE 3. SELECTED HUMAN CAPITAL AND LABOR MARKET CHARACTERISTICS OF MEN AND WOMEN GUESTWORKERS IN 1984 AND 1995

\begin{tabular}{|c|c|c|c|c|}
\hline & \multicolumn{2}{|c|}{ MEN } & \multicolumn{2}{|c|}{ WOMEN } \\
\hline & 1984 & 1995 & 1984 & 1995 \\
\hline & (1) & (2) & (3) & (4) \\
\hline Weekly Wages (in DM) ${ }^{1}$ & 678.62 & 945.56 & 454.24 & 699.63 \\
\hline Treiman Occupational Prestige Score ${ }^{1}$ & 34.62 & 35.37 & 32.38 & 34.22 \\
\hline Hours Worked Per Week ${ }^{1}$ & 42.15 & 41.04 & 37.26 & 35.38 \\
\hline Labor Force Participation (in \%) & 86 & 72 & 55 & 59 \\
\hline Not employed (in \%) & 8 & 18 & 40 & 31 \\
\hline Age in Years & 38.71 & 39.91 & 36.90 & 37.86 \\
\hline Years-Since-Migration & 15.95 & 24.53 & 15.78 & 24.30 \\
\hline Education in Country of Origin (in years) & 6.15 & 4.15 & 5.15 & 3.57 \\
\hline No degree in Germany (in \%) & 84 & 60 & 79 & 57 \\
\hline Primary-Secondary Degree in Germany & 11 & 19 & 14 & 19 \\
\hline Technical School Degree in Germany & 3 & 15 & 5 & 19 \\
\hline Academic High School Degree (Abitur) & 1 & 2 & 1 & 2 \\
\hline Other Degree in Germany (in \%) & 0 & 5 & 0 & 3 \\
\hline Vocational Training in Germany (in \%) & 17 & 22 & 16 & 24 \\
\hline Speak German Fluently (in \%) & 17 & 38 & 13 & 44 \\
\hline Married-Spouse in Germany (in \%) & 72 & 63 & 79 & 65 \\
\hline Married-Spouse not in Germany (in \%) & 5 & 2 & 1 & 0 \\
\hline Children in Household $<16$ yrs old & 55 & 42 & 61 & 46 \\
\hline Children in Home country $<18$ yrs old & 11 & 2 & 9 & 1 \\
\hline German Born (in \%) & 5 & 30 & 11 & 36 \\
\hline Feel totally German (in \%) & 4 & 5 & 4 & 8 \\
\hline German Citizen (in \%) & 4 & 26 & 6 & 33 \\
\hline Turk (in \%) & - & - & - & - \\
\hline Yugoslav (in \%) & 26 & 27 & 28 & 27 \\
\hline European Union Member Country (in\%) & 71 & 47 & 66 & 40 \\
\hline Remit (in \%) & 43 & 24 & 18 & 14 \\
\hline Own Dwelling in Germany (in \%) & 7 & 17 & 7 & 16 \\
\hline Number of Observations & 1048 & 728 & 939 & 730 \\
\hline${ }^{1}$ No of Obs on workers with $>0$ wages & 906 & 531 & 517 & 429 \\
\hline & 44 & & & \\
\hline
\end{tabular}




\begin{tabular}{|c|c|c|c|c|}
\hline & \multicolumn{2}{|c|}{ MEN } & \multicolumn{2}{|c|}{ WOMEN } \\
\hline & 1984 & 1995 & 1984 & 1995 \\
\hline & (5) & (6) & (7) & (8) \\
\hline Weekly Wages (in DM) ${ }^{1}$ & 589.09 & 919.62 & 398.44 & 621.50 \\
\hline Treiman Occupational Prestige Score ${ }^{1}$ & 33.59 & 33.11 & 29.53 & 29.67 \\
\hline Hours Worked Per Week ${ }^{1}$ & 41.22 & 40.31 & 36.69 & 32.22 \\
\hline Labor Force Participation (in \%) & 93 & 68 & 38 & 40 \\
\hline Not employed (in \%) & 12 & 15 & 57 & 52 \\
\hline Age in Years & 34.45 & 38.70 & 32.92 & 37.21 \\
\hline Years-Since-Migration & 12.63 & 20.29 & 11.15 & 17.25 \\
\hline Education in Country of Origin (in years) & 6.14 & 5.55 & 4.61 & 4.73 \\
\hline No degree in Germany (in \%) & 74 & 66 & 82 & 83 \\
\hline Primary-Secondary Degree in Germany & 18 & 20 & 14 & 11 \\
\hline Technical School Degree in Germany & 4 & 4 & 3 & 3 \\
\hline Academic High School Degree (Abitur) & 0 & 0 & 0 & 1 \\
\hline Other Degree in Germany (in \%) & 1 & 7 & 0 & 2 \\
\hline Vocational Training in Germany (in \%) & 22 & 21 & 9 & 8 \\
\hline Speak German Fluently (in \%) & 12 & 20 & 10 & 15 \\
\hline Married-Spouse in Germany (in \%) & 65 & 82 & 73 & 86 \\
\hline Married-Spouse not in Germany (in \%) & 7 & 2 & 2 & 2 \\
\hline Children in Household $<16 \mathrm{yrs}$ old & 71 & 61 & 79 & 70 \\
\hline Children in Home country $<18$ yrs old & 12 & 2 & 8 & 2 \\
\hline German Born (in \%) & 4 & 4 & 5 & 3 \\
\hline Feel totally German (in \%) & 3 & 2 & 3 & 1 \\
\hline German Citizen (in \%) & - & - & - & - \\
\hline Turk (in \%) & 100 & 100 & 100 & 100 \\
\hline Yugoslav (in \%) & - & - & - & - \\
\hline European Union Member Country (in\%) & - & - & - & - \\
\hline Remit (in \%) & 42 & 29 & 15 & 13 \\
\hline Own Dwelling in Germany (in \%) & 3 & 10 & 4 & 9 \\
\hline Number of Observations & 544 & 361 & 479 & 323 \\
\hline${ }^{1}$ No of Obs on workers with $>0$ wages & 435 & 247 & 181 & 129 \\
\hline
\end{tabular}


TABLE 5. MULTINOMIAL DISCRETE TIME EVENT HISTORY ANALYSIS OF THE LIKELIHOOD OF RETURN MIGRATION AMONG IMMIGRANTS TO GERMANY 1984-1997. COMPARISON OUTCOME IS THE PROBABILITY TO STAY

\begin{tabular}{|c|c|c|c|c|}
\hline \multirow[b]{2}{*}{ Predictor Variables } & \multicolumn{2}{|c|}{ Probability of Return Migration } & \multicolumn{2}{|c|}{ Probability of Leaving the Panel } \\
\hline & $\mathrm{B}$ & $\mathrm{SE}$ & $\mathrm{B}$ & $\mathrm{SE}$ \\
\hline \multicolumn{5}{|l|}{ THEORETICAL VARIABLES } \\
\hline \multicolumn{5}{|l|}{ Human Capital } \\
\hline Home Country Schooling & $0.0295^{\star}$ & 0.0140 & $-0.0164^{*}$ & 0.0050 \\
\hline Time Since Migration & -0.0218 & 0.0126 & $0.0134^{*}$ & 0.0052 \\
\hline Time Since Migration Squared & 0.0003 & 0.0003 & $-0.0004^{*}$ & 0.0001 \\
\hline \multicolumn{5}{|l|}{ German Degree } \\
\hline No Degree & - & - & - & - \\
\hline Primary-secondary & 0.0217 & 0.1379 & -0.0366 & 0.0444 \\
\hline Technical & -0.0890 & 0.2334 & 0.0430 & 0.0638 \\
\hline Abitur & -0.3683 & 0.4742 & $-0.4200^{\star}$ & 0.1490 \\
\hline Other & -0.0337 & 0.2607 & 0.0703 & 0.1308 \\
\hline German Vocational Training & -0.0433 & 0.1309 & 0.0218 & 0.0419 \\
\hline Fluent in German & $-0.3734^{*}$ & 0.1295 & 0.0472 & 0.0390 \\
\hline \multicolumn{5}{|l|}{ Work Effort } \\
\hline Full Time & - & - & - & - \\
\hline Part Time & 0.0548 & 0.2394 & 0.0474 & 0.0697 \\
\hline In Training & -0.0839 & 0.3297 & 0.0770 & 0.0788 \\
\hline \multicolumn{5}{|l|}{ Attachment to Employment } \\
\hline Marginally Employed & 0.5886 & 0.3441 & 0.2185 & 0.1185 \\
\hline Unemployed & $0.7776^{*}$ & 0.2093 & -0.0029 & 0.0682 \\
\hline Not Employed & $0.7686^{*}$ & 0.1943 & -0.0884 & 0.0561 \\
\hline \multicolumn{5}{|l|}{ Socioeconomic Achievement } \\
\hline Earnings & -0.0004 & 0.0002 & 0.0000 & 0.0001 \\
\hline Prestige & $-0.0085^{\star}$ & 0.0039 & 0.0016 & 0.0014 \\
\hline \multicolumn{5}{|l|}{ Attachment to Germany } \\
\hline Spouse in Germany & $-0.3317^{*}$ & 0.1098 & $-0.2739^{\star}$ & 0.0404 \\
\hline Children in Germany & $-0.2648^{*}$ & 0.0808 & $0.3122^{*}$ & 0.0291 \\
\hline German Born & -0.1741 & 0.1929 & 0.0403 & 0.0619 \\
\hline Own Home & $-0.3791^{*}$ & 0.1575 & $-0.1555^{\star}$ & 0.0470 \\
\hline Feel German & $-0.6386^{*}$ & 0.2922 & -0.0830 & 0.0638 \\
\hline German Citizen & $-0.7040^{*}$ & 0.2206 & $0.1788^{*}$ & 0.0632 \\
\hline \multicolumn{5}{|l|}{ Attachment to Origin } \\
\hline Spouse in Home Country & $0.9019^{*}$ & 0.1756 & $-0.3219^{*}$ & 0.0984 \\
\hline Children in Home Country & $0.3766^{*}$ & 0.1359 & -0.0171 & 0.0576 \\
\hline Remitted & $0.2668^{*}$ & 0.0964 & $-0.1016^{*}$ & 0.0353 \\
\hline \multicolumn{5}{|l|}{ CONTROL VARIABLES } \\
\hline \multicolumn{5}{|l|}{ Demographic } \\
\hline \multicolumn{5}{|l|}{ Age } \\
\hline $16-18$ & - & - & - & - \\
\hline $19-24$ & 0.2610 & 0.2073 & 0.0565 & 0.0645 \\
\hline $25-64$ & 0.1646 & 0.2205 & -0.1408 & 0.0735 \\
\hline $65+$ & $0.7064^{*}$ & 0.2718 & $-1.1922^{*}$ & 0.1983 \\
\hline Male & 0.0465 & 0.0857 & 0.0532 & 0.0309 \\
\hline
\end{tabular}

Continued 
TABLE 5. Continued

Predictor Variables

\begin{tabular}{|c|c|c|c|c|}
\hline \multicolumn{5}{|l|}{ CONTROL VARIABLES } \\
\hline \multicolumn{5}{|l|}{ National Origin } \\
\hline European Union & - & - & - & - \\
\hline Ex-Yugoslavia & $-1.0907^{*}$ & 0.1250 & -0.0660 & 0.0404 \\
\hline Turkey & $-0.8541^{*}$ & 0.0940 & -0.0412 & 0.0346 \\
\hline \multicolumn{5}{|l|}{ Place of Residence } \\
\hline Berlin & - & - & - & - \\
\hline Schleswig-Holstein & -0.2094 & 0.4001 & $0.2433^{*}$ & 0.1182 \\
\hline Hamburg & -0.3585 & 0.3168 & $-0.4507^{*}$ & 0.1055 \\
\hline Lower Saxony & $-0.5707^{*}$ & 0.2460 & $-1.1516^{*}$ & 0.0848 \\
\hline Bremen & 0.6786 & 0.4105 & -0.2203 & 0.1616 \\
\hline North Rhein-Westfalia & $-0.4530^{*}$ & 0.2105 & $-0.8114^{*}$ & 0.0674 \\
\hline Hessen & -0.4374 & 0.2250 & $-0.4348^{*}$ & 0.0709 \\
\hline Rheinland-Pfalz-Saarland & -0.4626 & 0.2562 & $-0.8921^{*}$ & 0.0891 \\
\hline Baden-Wurttemberg & $-0.6163^{*}$ & 0.2132 & $-1.1058^{*}$ & 0.0684 \\
\hline Bavaria & $-0.4635^{\star}$ & 0.2248 & $-0.9631^{*}$ & 0.0728 \\
\hline \multicolumn{5}{|l|}{ Period } \\
\hline 1984 & - & - & - & - \\
\hline 1985 & $-0.9485^{\star}$ & 0.1509 & $-0.2279^{*}$ & 0.0567 \\
\hline 1986 & $-1.1072^{*}$ & 0.1612 & $-0.3174^{*}$ & 0.0575 \\
\hline 1987 & $-0.6122^{*}$ & 0.1388 & $-0.4025^{\star}$ & 0.0581 \\
\hline 1988 & $-1.0660^{*}$ & 0.1614 & $-0.5015^{\star}$ & 0.0594 \\
\hline 1989 & $-1.2998^{*}$ & 0.1797 & $-0.5952^{*}$ & 0.0603 \\
\hline 1990 & $-1.6160^{*}$ & 0.2028 & $-0.6706^{*}$ & 0.0612 \\
\hline 1991 & $-1.6966^{*}$ & 0.2122 & $-0.8035^{\star}$ & 0.0625 \\
\hline 1992 & $-1.6412^{*}$ & 0.2057 & $-0.9473^{*}$ & 0.0644 \\
\hline 1993 & $-1.1858^{*}$ & 0.1764 & $-1.1246^{*}$ & 0.0667 \\
\hline 1994 & $-1.5236^{\star}$ & 0.1989 & $-1.3669^{*}$ & 0.0712 \\
\hline 1995 & $-1.3235^{\star}$ & 0.1882 & $-1.7684^{*}$ & 0.0798 \\
\hline $1996+$ & $-1.0315^{\star}$ & 0.1446 & $-2.9518^{*}$ & 0.0924 \\
\hline Intercept & $-1.0359^{*}$ & 0.3694 & $0.6926^{*}$ & 0.1247 \\
\hline \multirow{2}{*}{$\chi_{2}$} & \multicolumn{4}{|c|}{-20732.98} \\
\hline & \multicolumn{4}{|c|}{4790.80} \\
\hline Person Years & \multicolumn{4}{|c|}{33493} \\
\hline
\end{tabular}




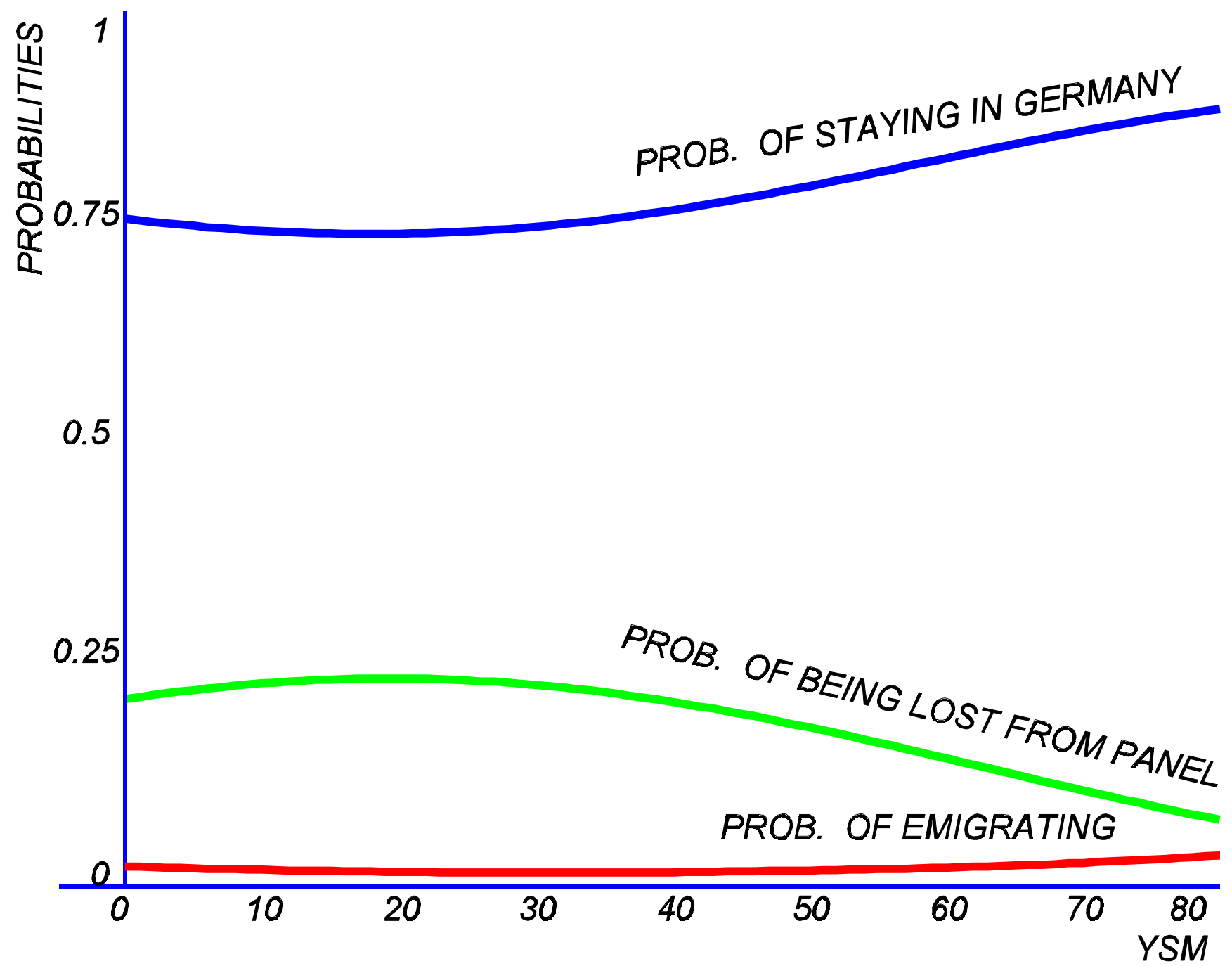

Figure 1: Probabilities of staying in Germany, of being lost to follow-up, and of emigrating with Years-sinceMigration, 1984-1997 


\begin{tabular}{|c|c|c|c|c|c|c|}
\hline \multirow[t]{2}{*}{ PARAMETERS } & \multicolumn{3}{|c|}{$\begin{array}{c}\text { COEFFICIENTS } \\
\text { (t-ratio) }\end{array}$} & \multicolumn{3}{|c|}{$\begin{array}{c}\text { COEFFICIENTS } \\
\text { (t-ratio) }\end{array}$} \\
\hline & (1) & (2) & (3) & (4) & (5) & (6) \\
\hline INTERCEPT & $\begin{array}{l}4.0654^{\star} \\
(34.80)\end{array}$ & $\begin{array}{l}4.1817^{\star} \\
(34.65)\end{array}$ & $\begin{array}{l}3.6808^{*} \\
(29.80)\end{array}$ & $\begin{array}{r}3.7930^{\star} \\
(27.79)\end{array}$ & $\begin{array}{l}3.9416^{*} \\
(27.88)\end{array}$ & $\begin{array}{l}3.4877^{\star} \\
(23.77)\end{array}$ \\
\hline AGE & $\begin{array}{l}0.0977^{*} \\
(15.56)\end{array}$ & $\begin{array}{l}0.0907^{*} \\
(13.26)\end{array}$ & $\begin{array}{l}0.0848^{*} \\
(12.83)\end{array}$ & $\begin{array}{c}0.11498 \\
(15.33)\end{array}$ & $\begin{array}{l}0.1050^{*} \\
(12.84)\end{array}$ & $\begin{array}{r}0.0980^{*} \\
(12.23)\end{array}$ \\
\hline $\mathrm{AGE}^{2}$ & $\begin{array}{l}-0.0011^{*} \\
(-14.97)\end{array}$ & $\begin{array}{l}-0.0011^{*} \\
(-13.10)\end{array}$ & $\begin{array}{l}-0.0010^{*} \\
(-12.66)\end{array}$ & $\begin{array}{c}-0.00136^{*} \\
(-14.58)\end{array}$ & $\begin{array}{c}-0.0013^{*} \\
(-12.51)\end{array}$ & $\begin{array}{l}-0.0012^{*} \\
(-11.90)\end{array}$ \\
\hline YSM & $\begin{array}{c}-0.0080^{*} \\
(-1.93)\end{array}$ & $\begin{array}{c}-0.0078 \\
(-1.88)\end{array}$ & $\begin{array}{c}-0.0067 \\
(-1.68)\end{array}$ & $\begin{array}{l}-0.0127^{\star} \\
(-2.65)\end{array}$ & $\begin{array}{c}-0.0122^{*} \\
(-2.55)\end{array}$ & $\begin{array}{c}-0.0109^{*} \\
(-2.29)\end{array}$ \\
\hline $\mathrm{YSM}^{2}$ & $\begin{array}{c}0.0003^{*} \\
(3.07)\end{array}$ & $\begin{array}{c}0.0003^{*} \\
(2.97)\end{array}$ & $\begin{array}{c}0.0002^{*} \\
(2.65)\end{array}$ & $\begin{array}{c}0.0003^{*} \\
(3.34)\end{array}$ & $\begin{array}{c}0.0003^{*} \\
(3.16)\end{array}$ & $\begin{array}{c}0.0003^{*} \\
(2.91)\end{array}$ \\
\hline SEX & $\begin{array}{c}0.3768^{*} \\
(18.99)\end{array}$ & $\begin{array}{c}0.3779^{*} \\
(19.02)\end{array}$ & $\begin{array}{l}0.3046^{*} \\
(15.63)\end{array}$ & $\begin{array}{l}0.3801^{*} \\
(16.61)\end{array}$ & $\begin{array}{l}0.3806^{*} \\
(16.69)\end{array}$ & $\begin{array}{l}0.3076^{*} \\
(13.58)\end{array}$ \\
\hline PRIMARY-SECONDARY & $\begin{array}{c}-0.0585 \\
(-1.42)\end{array}$ & $\begin{array}{c}-0.0370 \\
(-0.89)\end{array}$ & $\begin{array}{c}-0.0078 \\
(-0.20)\end{array}$ & $\begin{array}{c}-0.0422 \\
(-0.91)\end{array}$ & $\begin{array}{l}-0.0233 \\
(-0.50)\end{array}$ & $\begin{array}{c}0.00016 \\
(0.00)\end{array}$ \\
\hline TECHNICAL DEGREE & $\begin{array}{c}-0.0871 \\
(-1.43)\end{array}$ & $\begin{array}{c}-0.0872 \\
(-1.43)\end{array}$ & $\begin{array}{l}-0.0420 \\
(-0.71)\end{array}$ & $\begin{array}{l}-0.053 \\
(-0.78)\end{array}$ & $\begin{array}{c}-0.0527 \\
(-0.78)\end{array}$ & $\begin{array}{r}-0.0170 \\
(-0.26)\end{array}$ \\
\hline ABITUR & $\begin{array}{l}0.1871 \\
(1.66)\end{array}$ & $\begin{array}{c}0.2272^{*} \\
(2.02)\end{array}$ & $\begin{array}{c}0.2447^{*} \\
(2.28)\end{array}$ & $\begin{array}{r}0.2027 \\
(1.67)\end{array}$ & $\begin{array}{c}0.2456^{*} \\
(2.03)\end{array}$ & $\begin{array}{c}0.2723^{*} \\
(2.35)\end{array}$ \\
\hline OTHER DEGREE IN G & $\begin{array}{r}-0.1124 \\
(-0.84)\end{array}$ & $\begin{array}{c}-0.0942 \\
(-0.71)\end{array}$ & $\begin{array}{l}-0.0765 \\
(-0.61)\end{array}$ & $\begin{array}{c}-0.1481 \\
(-1.02)\end{array}$ & $\begin{array}{c}-0.1172 \\
(-0.81)\end{array}$ & $\begin{array}{c}-0.1020 \\
(-0.74)\end{array}$ \\
\hline VOC'L TRAINING IN G & $\begin{array}{c}-0.0856^{*} \\
(-2.75)\end{array}$ & $\begin{array}{c}-0.0891^{*} \\
(-2.87)\end{array}$ & $\begin{array}{c}-0.1108^{*} \\
(-3.74)\end{array}$ & $\begin{array}{c}-0.0721^{*} \\
(-2.07)\end{array}$ & $\begin{array}{c}-0.0751^{*} \\
(-2.17)\end{array}$ & $\begin{array}{c}-0.093^{*} \\
(-2.78)\end{array}$ \\
\hline EDU HOME COUNTRY & $\begin{array}{c}0.0159^{*} \\
(4.47)\end{array}$ & $\begin{array}{c}0.0145^{*} \\
(4.07)\end{array}$ & $\begin{array}{c}0.0085^{*} \\
(2.46)\end{array}$ & $\begin{array}{c}0.0164^{*} \\
(4.00)\end{array}$ & $\begin{array}{c}0.0147^{*} \\
(3.58)\end{array}$ & $\begin{array}{c}0.0103^{*} \\
(2.56)\end{array}$ \\
\hline SPEAK G FLUENTLY & $\begin{array}{c}0.0690^{*} \\
(2.33)\end{array}$ & $\begin{array}{c}0.0720^{*} \\
(2.44)\end{array}$ & $\begin{array}{l}0.0237 \\
(0.83)\end{array}$ & $\begin{array}{c}0.0737^{\star} \\
(2.27)\end{array}$ & $\begin{array}{c}0.07796^{*} \\
(2.41)\end{array}$ & $\begin{array}{c}0.0361 \\
(1.15)\end{array}$ \\
\hline MAR_SPOUSE IN G & & $\begin{array}{l}0.1406^{*} \\
(4.560)\end{array}$ & $\begin{array}{r}0.1454^{*} \\
(4.99)\end{array}$ & & $\begin{array}{l}0.1553^{*} \\
(4.48)\end{array}$ & $\begin{array}{r}0.1589^{*} \\
(4.80)\end{array}$ \\
\hline MAR NO SPOUSE IN G & & $\begin{array}{c}0.1529 * \\
(2.86)\end{array}$ & $\begin{array}{l}0.1769^{*} \\
(3.49)\end{array}$ & & $\begin{array}{l}0.1989^{*} \\
(2.95)\end{array}$ & $\begin{array}{c}0.2093^{*} \\
(3.24)\end{array}$ \\
\hline KIDS IN HH & & $\begin{array}{c}-0.0749 * \\
(-3.46)\end{array}$ & $\begin{array}{c}-0.0558^{*} \\
(-2.68)\end{array}$ & & $\begin{array}{c}-0.0616^{*} \\
(-2.45)\end{array}$ & $\begin{array}{r}-0.0512^{*} \\
(-2.11)\end{array}$ \\
\hline KIDS IN NATIVE & & $\begin{array}{l}-0.0375 \\
(-1.19)\end{array}$ & $\begin{array}{l}-0.0302 \\
(-1.01)\end{array}$ & & $\begin{array}{l}-0.0440 \\
(-1.19)\end{array}$ & $\begin{array}{l}-0.0351 \\
(-0.99)\end{array}$ \\
\hline HOURS PER WEEK & & & $\begin{array}{c}0.0128^{*} \\
(13.71)\end{array}$ & & & $\begin{array}{l}0.0125^{*} \\
(11.58)\end{array}$ \\
\hline PRESTIGE SCORE & & & $\begin{array}{c}0.0057^{*} \\
(5.31)\end{array}$ & & & $\begin{array}{r}0.0048^{*} \\
(3.80)\end{array}$ \\
\hline GERMAN CITIZEN & & & $\begin{array}{l}-0.2811^{*} \\
(-4.48)\end{array}$ & & & $\begin{array}{l}-0.2485^{*} \\
(-3.72)\end{array}$ \\
\hline EX-YUGOSLAV & & & $\begin{array}{l}-0.0216 \\
(-0.89)\end{array}$ & & & $\begin{array}{l}-0.0283 \\
(-1.01)\end{array}$ \\
\hline TURK & & & $-0.0593^{*}$ & & & -0.041 \\
\hline
\end{tabular}


TABLE 6. ESTIMATED EARNINGS EQUATIONS RESULTS IN 1984

\begin{tabular}{lcccccc}
\hline & \multicolumn{3}{r}{$\begin{array}{r}\text { ENTIRE GUESTWORKER } \\
\text { POPULATION IN 1984 }\end{array}$} & \multicolumn{2}{c}{$\begin{array}{c}\text { GUESTWORKERS WHO DID } \\
\text { NOT EMIGRATE IN 1984 }\end{array}$} \\
\hline & & & $(-2.77)$ & & $(-1.64)$ \\
$\mathrm{R}^{2}$ & 0.337 & 0.385 & 0.452 & 0.394 & 0.403 & 0.459 \\
F statistic & 102.16 & 79.14 & 79.25 & 87.15 & 67.61 & 64.63 \\
Mean of Ln Weekly Wages & & 6.248 & & & 6.243 & 1619
\end{tabular}

Note:* indicates significance at the 5 per cent level in two-tailed test $(p<0.05)$ 
TABLE 7. EMPLOYMENT PROBABILITY RESULTS FOR MEN AND WOMEN IN 1984

\begin{tabular}{|c|c|c|}
\hline & $\begin{array}{l}\text { ENTIRE GUESTWORKER } \\
\text { POPULATION IN } 1984\end{array}$ & $\begin{array}{l}\text { GUESTWORKERS WHO DID } \\
\text { NOT EMIGRATE IN } 1984\end{array}$ \\
\hline PREDICTOR VARIABLES & $\begin{array}{c}\text { COEFFICIENTS } \\
\text { (St. Error) }\end{array}$ & $\begin{array}{c}\text { COEFFICIENTS } \\
\text { (St. Error) }\end{array}$ \\
\hline INTERCEPT & $\begin{array}{l}-2.8707^{*} \\
(0.2982)\end{array}$ & $\begin{array}{l}-2.7885^{*} \\
(0.3596)\end{array}$ \\
\hline AGE & $\begin{array}{l}\mathbf{0 . 1 4 0 4}^{\star} \\
(0.0176)\end{array}$ & $\begin{array}{l}\mathbf{0 . 1 3 1 1}^{*} \\
(0.0216)\end{array}$ \\
\hline $\mathrm{AGE}^{2}$ & $\begin{array}{l}-0.0018^{*} \\
(0.0002)\end{array}$ & $\begin{array}{l}-0.0016^{*} \\
(0.0003)\end{array}$ \\
\hline YSM & $\begin{array}{l}\mathbf{0 . 0 2 8 2}^{\star} \\
(0.0106)\end{array}$ & $\begin{array}{l}\mathbf{0 . 0 3 7 4}^{\star} \\
(0.0123)\end{array}$ \\
\hline $\mathrm{YSM}^{2}$ & $\begin{array}{l}-0.0005^{*} \\
(0.0002)\end{array}$ & $\begin{array}{l}-0.0007^{*} \\
(0.0002)\end{array}$ \\
\hline SEX & $\begin{array}{l}\mathbf{0 . 8 7 1 1 ^ { * }} \\
(0.0568)\end{array}$ & $\begin{array}{l}\mathbf{0 . 9 6 5 3 *}^{*} \\
(0.0660)\end{array}$ \\
\hline PRIMARY-SECONDARY IN G & $\begin{array}{l}\mathbf{0 . 2 6 4 6}^{*} \\
(0.1073)\end{array}$ & $\begin{array}{c}0.2056 \\
(0.1221)\end{array}$ \\
\hline TECHNICAL DEGREE IN G & $\begin{array}{c}0.1039 \\
(0.1549)\end{array}$ & $\begin{array}{c}0.0385 \\
(0.1722)\end{array}$ \\
\hline ABITUR IN GERMANY & $\begin{array}{l}-0.3129 \\
(0.2786)\end{array}$ & $\begin{array}{l}-0.3568 \\
(0.3025)\end{array}$ \\
\hline OTHER DEGREE IN G & $\begin{array}{l}-0.3837 \\
(0.3524)\end{array}$ & $\begin{array}{l}-0.4960 \\
(0.3571)\end{array}$ \\
\hline VOC'L TRAINING IN G & $\begin{array}{l}0.4090^{\star} \\
(0.0901)\end{array}$ & $\begin{array}{l}\mathbf{0 . 4 5 2 7}^{\star} \\
(0.1019)\end{array}$ \\
\hline EDU IN HOME COUNTRY & $\begin{array}{l}0.0375^{\star} \\
(0.0099)\end{array}$ & $\begin{array}{l}\mathbf{0 . 0 3 8 2}^{\star} \\
(0.0116)\end{array}$ \\
\hline SPEAK GERMAN FLUENTLY & $\begin{array}{l}-0.0572 \\
(0.0868)\end{array}$ & $\begin{array}{c}0.0313 \\
(0.0983)\end{array}$ \\
\hline MARRIED-SPOUSE IN G & $\begin{array}{l}-0.2016^{\star} \\
(0.0884)\end{array}$ & $\begin{array}{l}-0.1976 \\
(0.1015)\end{array}$ \\
\hline MARRIED-NO SPOUSE IN G & $\begin{array}{l}-0.0439 \\
(0.2085)\end{array}$ & $\begin{array}{c}0.1087 \\
(0.3010)\end{array}$ \\
\hline KIDS IN HOUSEHOLD & $\begin{array}{l}-0.1555^{*} \\
(0.0644)\end{array}$ & $\begin{array}{l}-0.1686^{*} \\
(0.0760)\end{array}$ \\
\hline KIDS IN NATIVE COUNTRY & $\begin{array}{c}0.0528 \\
(0.1061)\end{array}$ & $\begin{array}{c}0.1247 \\
(0.1310)\end{array}$ \\
\hline OWN DWELLING & $\begin{array}{l}0.2130 \\
(0.1191)\end{array}$ & $\begin{array}{c}0.1700 \\
(0.1302)\end{array}$ \\
\hline REMIT & $\begin{array}{l}0.7939^{\star} \\
(0.0719)\end{array}$ & $\begin{array}{l}\mathbf{0 . 8 2 6 6}^{\star} \\
(0.0859)\end{array}$ \\
\hline GERMAN CITIZEN & $\begin{array}{c}-0.2392 \\
(0.1550)\end{array}$ & $\begin{array}{c}-0.2435 \\
(0.1678)\end{array}$ \\
\hline EX-YUGOSLAV & $\begin{array}{c}0.0251 \\
(0.0802)\end{array}$ & $\begin{array}{l}-0.0355 \\
(0.0925)\end{array}$ \\
\hline TURK & $\begin{array}{c}-0.2296^{*} \\
(0.0643)\end{array}$ & $\begin{array}{l}-0.2694^{\star} \\
(0.0760)\end{array}$ \\
\hline \multirow{2}{*}{$\mathrm{\chi}_{2}^{\mathrm{LOG} \text { LIKELIHOOD }}$} & -1466.797 & -1082.588 \\
\hline & 851.825 & 708.606 \\
\hline NUMBER OF OBSERVATIONS & 3010 & 2333 \\
\hline
\end{tabular}


PREDICTOR VARIABLES

INTERCEPT

AGE

$\mathrm{AGE}^{2}$

YSM

YSM $^{2}$

SEX

PRIMARY-SECONDARY DEGREE IN G

TECHNICAL DEGREE IN G

ABITUR IN GERMANY

OTHER DEGREE IN GERMANY

VOC'L TRAINING IN G

EDU IN HOME COUNTRY

SPEAK GERMAN FLUENTLY

HOURS WORKING PER WEEK

TREIMAN PRESTIGE SCORE

GERMAN CITIZEN

EX-YUGOSLAV

TURK

$\lambda$

MEAN LN WAGE

(STD. DEVIATION OF WAGE)

LOG LIKELIHOOD

$\mathrm{R}^{2}$

F STATISTIC

NUMBER OF OBSERVATIONS

${ }^{*} p<0.05$
ENTIRE GUESTWORKER GUESTWORKERS WHO DID POPULATION IN 1984 COEFFICIENTS

(St. Error)

$3.8922^{*}$

$(0.1708)$

$0.0839^{*}$

$(0.0071)$

$-0.0010^{*}$

$(0.0001)$

$-0.0093^{*}$

$(0.0042)$

$\mathbf{0 . 0 0 0 3}^{*}$

$(0.0001)$

$0.2382^{*}$

$(0.0312)$

$-0.0497$

$(0.0407)$

$-0.0456$

(0.0605)

0.2143

$(0.1100)$

$-0.0862$

(0.1296)

$-0.1320^{*}$

$(0.0318)$

$\mathbf{0 . 0 0 7 4}^{*}$

$(0.0037)$

0.0252

(0.0292)

$0.0127^{*}$

(0.0009)

$0.0055^{*}$

$(0.0011)$

$-0.2706^{*}$

(0.0646)

$-0.0297$

$(0.0248)$

-0.0496 *

$(0.0221)$

$-0.1535^{\star}$

$(0.0546)$

6.2483

0.5235

$-960.4743$

0.4465

$F[18,2020]=90.54$

2039
NOT EMIGRATE IN 1984

COEFFICIENTS

(St. Error)

3.5785*

(0.1945)

$0.1021^{*}$

$(0.0083)$

$-0.0012^{*}$

(0.0001)

$-0.0131^{*}$

(0.0049)

$\mathbf{0 . 0 0 0 3}^{*}$

(0.0001)

$\mathbf{0 . 2 5 3 3}^{*}$

(0.0365)

$-0.0323$

(0.0453)

$-0.0178$

(0.0669)

0.2386

(0.1176)

$-0.1206$

(0.1398)

$-0.1108^{*}$

(0.0356)

$0.0101^{*}$

$(0.0042)$

0.0317

(0.0319)

$0.0125^{*}$

(0.0011)

$\mathbf{0 . 0 0 4 7}^{*}$

(0.0013)

-0.2429 *

(0.0678)

$-0.0321$

(0.0280)

$-0.0278$

(0.0258)

$-0.1191$

(0.0623)

6.2429

0.5431

$-812.2432$

0.4519

$F[18,1600]=73.28$

1619 


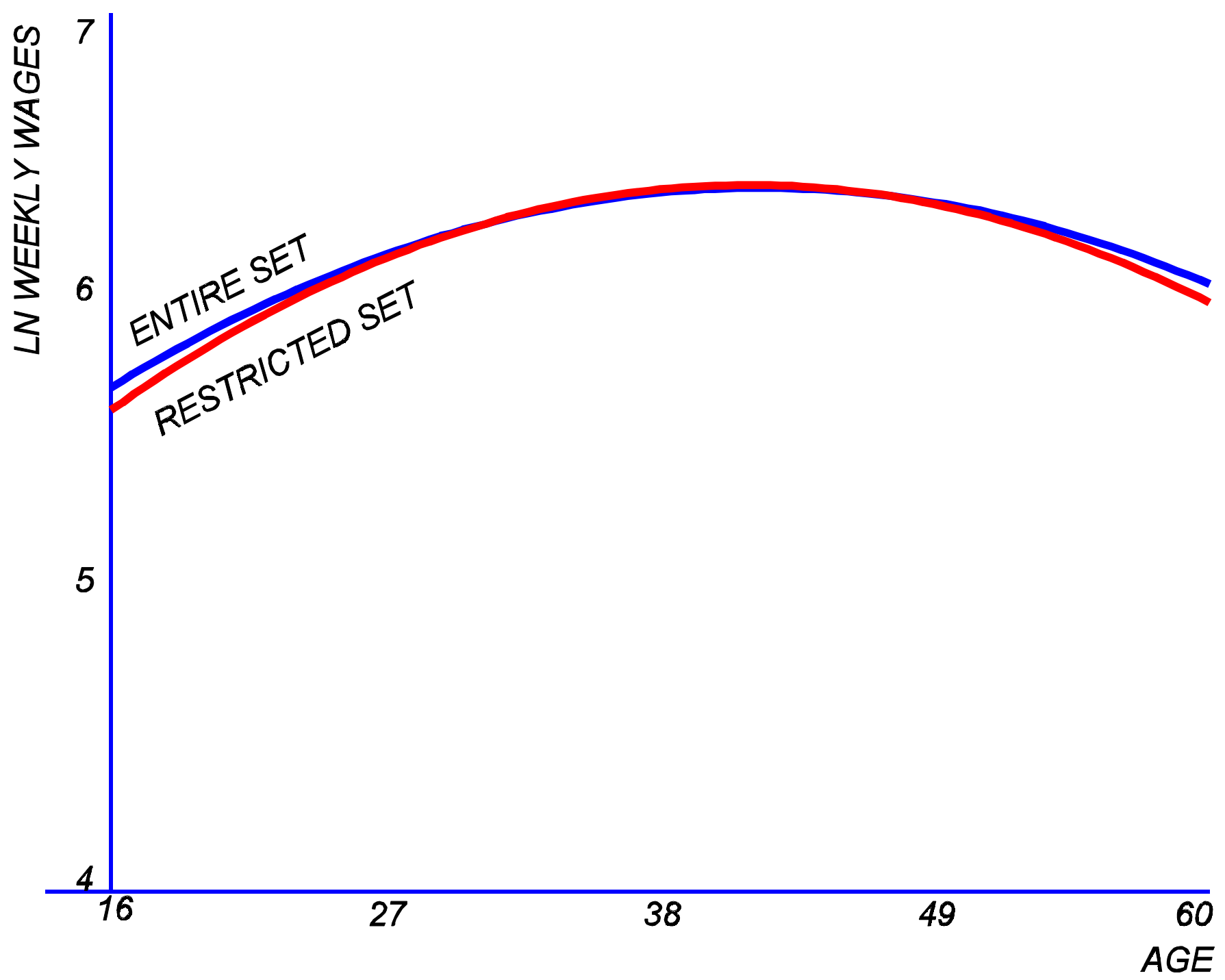

Figure 2: Age/Earnings Profiles of Guestworkers in 1984 


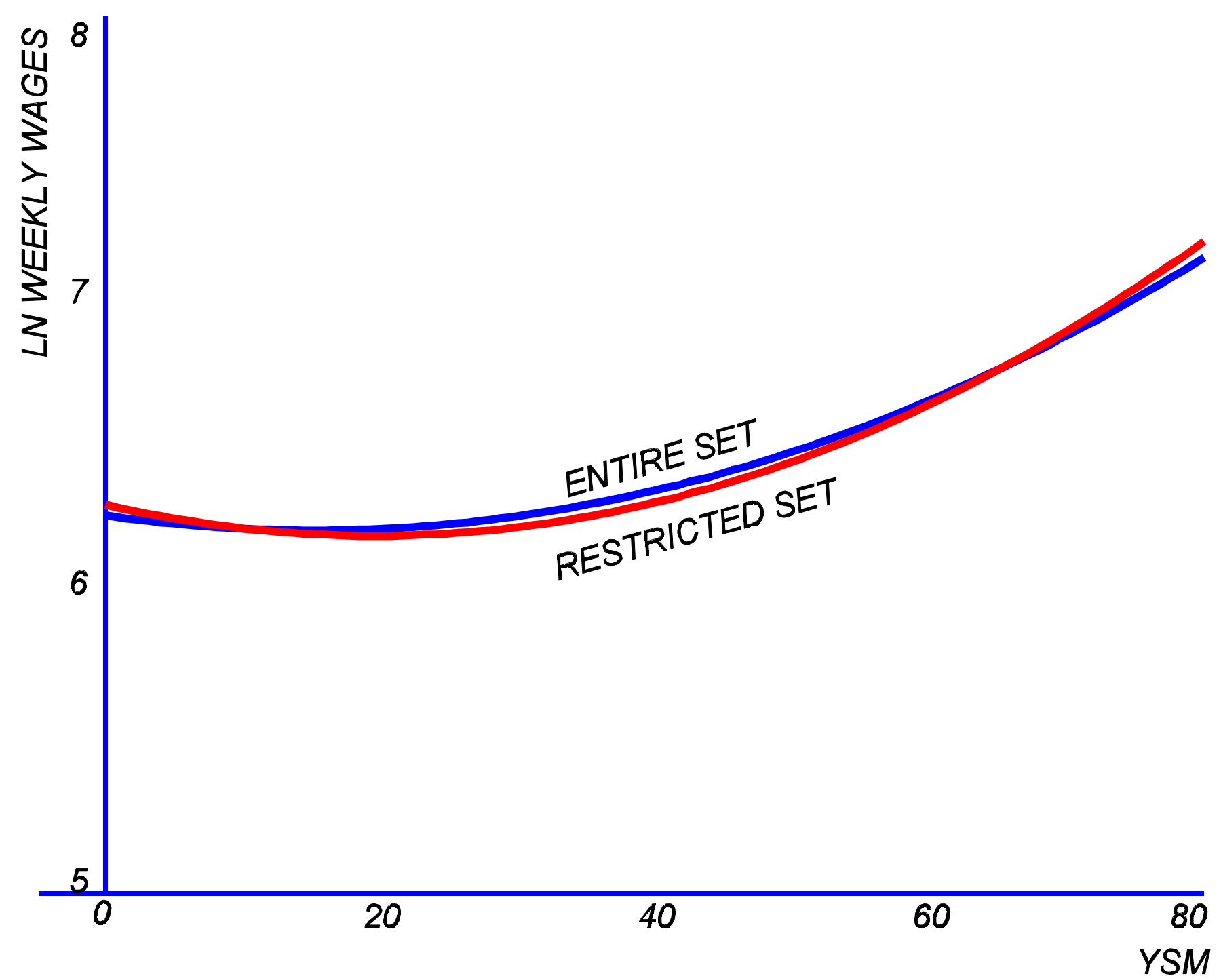

Figure 3: YSM/Earnings Profiles of Guestworkers in Germany in 1984 


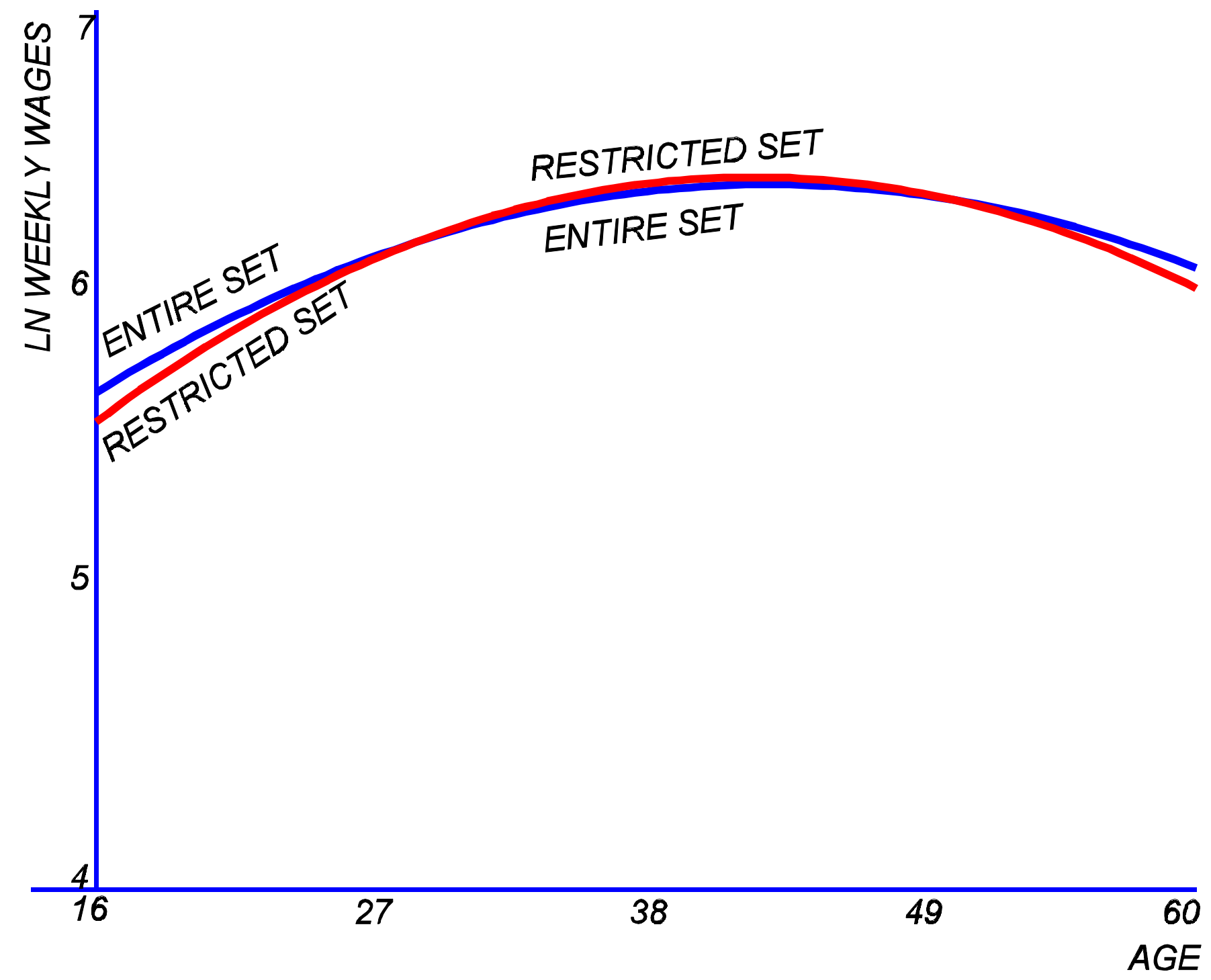

Figure 4: Age/Earnings Profiles of Guestworkers in 1984, Adjusted for Selection 


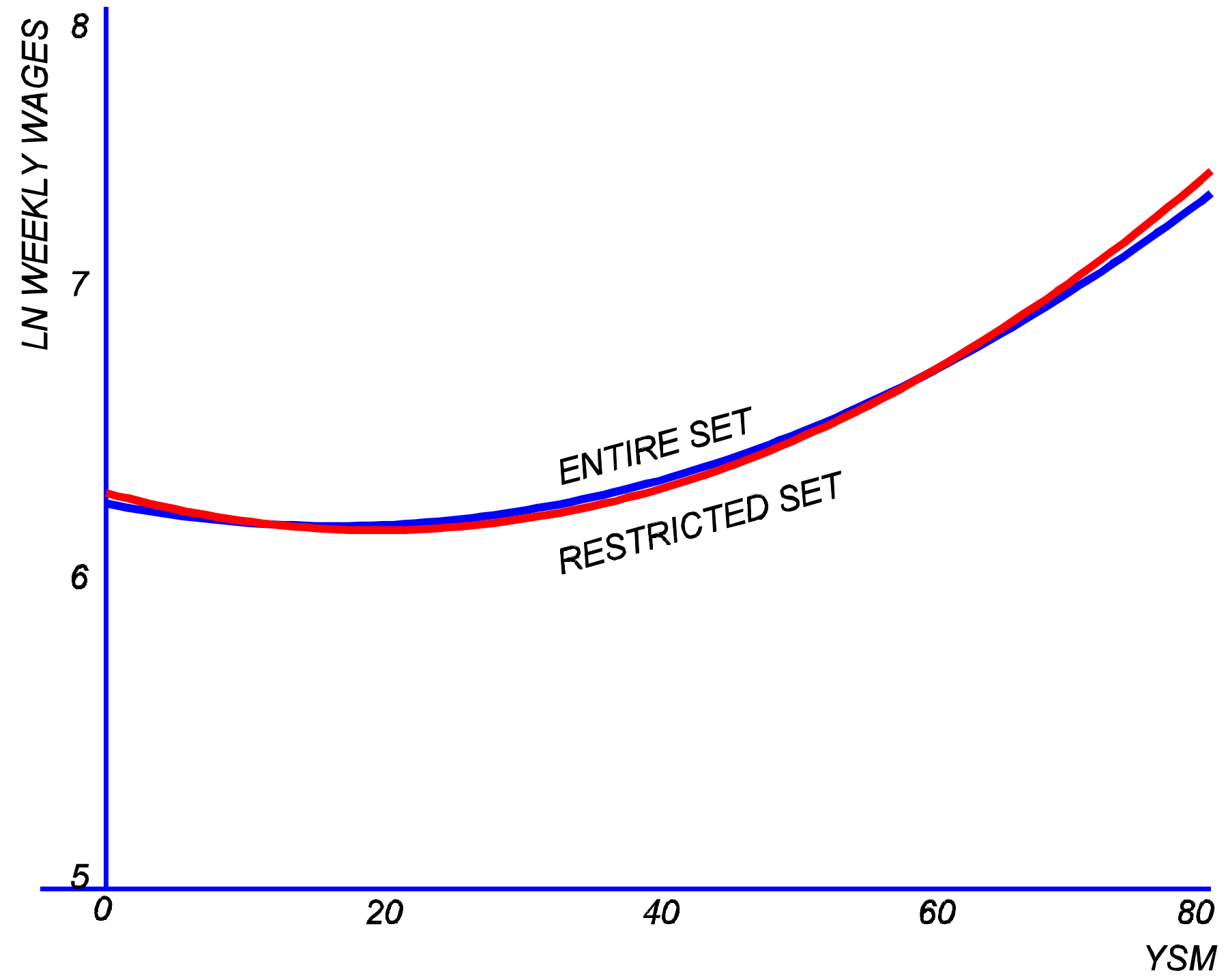

Figure 5: YSM/Earnings Profiles of Guestworkers in Germany in 1984, Adjusted for Selection 


\section{APPENDIX}

TABLE A3.1 SUMMARY STATISTICS OF HUMAN CAPITAL, EARNINGS, AND OCCUPATION BY NATIONALITY. ENTIRE DATA SET IN 1984

\begin{tabular}{|c|c|c|c|c|}
\hline & GERMAN & TURK & YUGO & EU \\
\hline WEEKLY WAGES IN DM ${ }^{1}$ & 360.23 & 533.07 & 615.90 & 601.75 \\
\hline TREIMAN PRESTIGE SCORE ${ }^{1}$ & 38.63 & 32.40 & 33.66 & 33.61 \\
\hline NO DEGREE IN GERMANY(\%) & 0.12 & 0.78 & 0.90 & 0.84 \\
\hline ABITUR (\%) & 0.04 & 0.00 & 0.01 & 0.01 \\
\hline VOC'L TRAINING IN G (\%) & 0.64 & 0.16 & 0.11 & 0.15 \\
\hline SPK GERMAN FLUENTLY (\%) & 0.41 & 0.11 & 0.18 & 0.12 \\
\hline EDUHOME (IN YRS) & 0.75 & 5.42 & 6.68 & 5.63 \\
\hline Observations & 94 & 1023 & 537 & 1356 \\
\hline Percent of total obs (3010) & 3 & 34 & 18 & 45 \\
\hline${ }^{1}$ Observations (with $>0$ wages only) & 51 & 616 & 403 & 969 \\
\hline
\end{tabular}

TABLE A3.2 SUMMARY STATISTICS OF HUMAN CAPITAL, EARNINGS, AND OCCUPATION BY NATIONALITY, 1995. ENTIRE DATA SET

\begin{tabular}{lcccc}
\hline & GERMAN & TURK & YUGO & EU \\
\hline WEEKLY WAGES IN DM & & & \\
& 760.70 & 817.34 & 835.56 & 888.69 \\
TREIMAN PRESTIGE SCORE & 37.36 & 31.93 & 33.43 & 34.06 \\
NO DEGREE IN GERMANY(\%) & 0.19 & 0.74 & 0.75 & 0.74 \\
ABITUR (\%) & 0.03 & 0.01 & 0.01 & 0.02 \\
VOC'L TRAINING IN G (\%) & 0.37 & 0.15 & 0.15 & 0.18 \\
SPK GERMAN FLUENTLY (\%) & 0.79 & 0.18 & 0.28 & 0.23 \\
EDUHOME (IN YRS) & 0.57 & 5.16 & 5.76 & 4.91 \\
Observations & 430 & 684 & 394 & 634 \\
Percent of total obs (2142) & 20 & 32 & 18 & 30 \\
${ }^{1}$ Observations (with >0 wages only) & 284 & 376 & 274 & 402
\end{tabular}


TABLE A5.1 MULTINOMIAL DISCRETE TIME EVENT HISTORY ANALYSIS OF THE LIKELIHOOD OF RETURN MIGRATION AMONG MALE IMMIGRANTS TO GERMANY 1984-1997. COMPARISON OUTCOME IS THE PROBABILITY TO STAY

\begin{tabular}{|c|c|c|c|c|}
\hline \multirow[b]{2}{*}{ Predictor Variables } & \multicolumn{2}{|c|}{ Probability of Return Migration } & \multicolumn{2}{|c|}{ Probability of Lost to Follow-Up } \\
\hline & $\mathrm{B}$ & SE & $\mathrm{B}$ & SE \\
\hline \multicolumn{5}{|l|}{ THEORETICAL VARIABLES } \\
\hline \multicolumn{5}{|l|}{ Human Capital } \\
\hline Home Country Schooling & 0.0282 & 0.0203 & 0.0058 & 0.0071 \\
\hline Time Since Migration & $-0.0462^{*}$ & 0.0221 & 0.0008 & 0.0081 \\
\hline Time Since Migration Squared & 0.0003 & 0.0005 & 0.0000 & 0.0002 \\
\hline \multicolumn{5}{|l|}{ German Degree } \\
\hline No Degree & - & - & - & - \\
\hline Primary-secondary & -0.3495 & 0.2191 & -0.0650 & 0.0619 \\
\hline Technical & -0.3922 & 0.3505 & $-0.2932^{*}$ & 0.0923 \\
\hline Abitur - Other & -0.2219 & 0.3037 & $-0.3173^{*}$ & 0.1384 \\
\hline German Vocational Training & 0.0981 & 0.1742 & $0.1107^{*}$ & 0.0551 \\
\hline Fluent in German & $-0.5242^{*}$ & 0.1929 & -0.0689 & 0.0532 \\
\hline \multicolumn{5}{|l|}{ Work Effort } \\
\hline Full Time & - & - & - & - \\
\hline Part Time, In Training & -0.0947 & 0.4140 & -0.0023 & 0.0960 \\
\hline \multicolumn{5}{|l|}{ Attachment to Employment } \\
\hline Unemployed & $0.8901^{*}$ & 0.2821 & 0.0404 & 0.0920 \\
\hline Not Employed & $1.3260^{*}$ & 0.2782 & $-0.2430^{*}$ & 0.0919 \\
\hline \multicolumn{5}{|l|}{ Socioeconomic Achievement } \\
\hline Earnings & -0.0004 & 0.0003 & $0.0002^{*}$ & 0.0001 \\
\hline Prestige & 0.0067 & 0.0063 & -0.0011 & 0.0023 \\
\hline \multicolumn{5}{|l|}{ Attachment to Germany } \\
\hline Spouse in Germany & $-0.4184^{*}$ & 0.1675 & $-0.3782^{*}$ & 0.0594 \\
\hline Children in Germany & -0.1793 & 0.1208 & $0.2959^{*}$ & 0.0405 \\
\hline German Born & -0.2476 & 0.3231 & $0.3583^{*}$ & 0.0884 \\
\hline Own Home & $-0.4751^{*}$ & 0.2276 & $-0.2650^{*}$ & 0.0659 \\
\hline Feel German & -0.9118 & 0.5169 & 0.0309 & 0.0922 \\
\hline German Citizen & $-0.8172^{*}$ & 0.3835 & 0.1678 & 0.0916 \\
\hline \multicolumn{5}{|l|}{ Attachment to Origin } \\
\hline Spouse in Home Country & $0.8701^{*}$ & 0.2333 & $-0.5832^{*}$ & 0.1226 \\
\hline Children in Home Country & 0.3348 & 0.1882 & 0.0107 & 0.0771 \\
\hline Remitted & 0.2067 & 0.1269 & $-0.1153^{*}$ & 0.0443 \\
\hline
\end{tabular}

\section{CONTROL VARIABLES}

Demographic

Age

16-18

19-24

25-64

$65+$

$\begin{array}{llrl}0.7673^{*} & 0.3597 & 0.0622 & 0.0914 \\ 0.9578^{*} & 0.3777 & -0.1375 & 0.1074 \\ 1.3366^{*} & 0.4432 & -1.2436^{*} & 0.3212\end{array}$

Continued 
TABLE A5.1 Continued

Probability of Return Migration Probability of Lost to Follow-Up

\begin{tabular}{|c|c|c|c|c|}
\hline Predictor Variables & $\mathrm{B}$ & SE & $\mathrm{B}$ & SE \\
\hline \multicolumn{5}{|l|}{ CONTROL VARIABLES } \\
\hline \multicolumn{5}{|l|}{ National Origin } \\
\hline European Union & - & - & - & - \\
\hline Ex-Yugoslavia & $-1.1942^{*}$ & 0.1812 & $-0.1402^{\star}$ & 0.0563 \\
\hline Turkey & $-0.9356^{\star}$ & 0.1327 & $-0.1432^{*}$ & 0.0476 \\
\hline \multicolumn{5}{|l|}{ Place of Residence } \\
\hline Berlin & - & - & - & 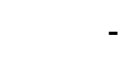 \\
\hline Schleswig-Holstein & 0.2712 & 0.5593 & $0.3770^{*}$ & 0.1728 \\
\hline Hamburg & -0.3311 & 0.4622 & $-0.4804^{\star}$ & 0.1479 \\
\hline Lower Saxony & -0.3930 & 0.3576 & -1.2273 & 0.1189 \\
\hline Bremen & 1.1065 & 0.5763 & $-0.1194^{*}$ & 0.2220 \\
\hline North Rhein-Westfalia & -0.3157 & 0.3116 & $-0.8533^{\star}$ & 0.0956 \\
\hline Hessen & -0.2895 & 0.3343 & $-0.6274^{*}$ & 0.1013 \\
\hline Rheinland-Pfalz-Saarland & -0.2562 & 0.3785 & $-1.0358^{*}$ & 0.1266 \\
\hline Baden-Wurttemberg & -0.4359 & 0.3145 & $-1.1588^{*}$ & 0.0968 \\
\hline Bavaria & -0.3790 & 0.3363 & $-1.0697^{\star}$ & 0.1035 \\
\hline \multicolumn{5}{|l|}{ Period } \\
\hline 1984 & - & - & - & - \\
\hline 1985 & $-0.9344^{*}$ & 0.2209 & $-0.2218^{*}$ & 0.0777 \\
\hline 1986 & $-1.0544^{\star}$ & 0.2335 & $-0.3044^{\star}$ & 0.0786 \\
\hline 1987 & $-0.4648^{*}$ & 0.1990 & $-0.3796^{\star}$ & 0.0798 \\
\hline 1988 & $-0.7901^{*}$ & 0.2247 & $-0.4821^{*}$ & 0.0820 \\
\hline 1989 & $-1.0499^{*}$ & 0.2539 & $-0.5825^{\star}$ & 0.0838 \\
\hline 1990 & $-1.3247^{\star}$ & 0.2811 & $-0.6405^{\star}$ & 0.0848 \\
\hline 1991 & $-1.6572^{*}$ & 0.3236 & $-0.7757^{\star}$ & 0.0867 \\
\hline 1992 & $-1.4848^{*}$ & 0.3013 & $-0.9415^{\star}$ & 0.0899 \\
\hline 1993 & $-0.8307^{\star}$ & 0.2449 & $-1.1032^{*}$ & 0.0930 \\
\hline 1994 & $-1.3242^{*}$ & 0.2915 & $-1.3544^{*}$ & 0.1002 \\
\hline 1995 & $-1.1003^{*}$ & 0.2746 & $-1.7936^{*}$ & 0.1135 \\
\hline $1996+$ & $-0.7157^{\star}$ & 0.2134 & $-3.0512^{*}$ & 0.1341 \\
\hline Intercept & $-2.0549^{*}$ & 0.5713 & $0.9780^{*}$ & 0.1796 \\
\hline \multirow{2}{*}{$\chi_{2}^{\text {Log Likelihood }}$} & \multicolumn{4}{|c|}{-10674.06} \\
\hline & \multicolumn{4}{|c|}{2745.56} \\
\hline Person Years & \multicolumn{4}{|c|}{17405} \\
\hline
\end{tabular}




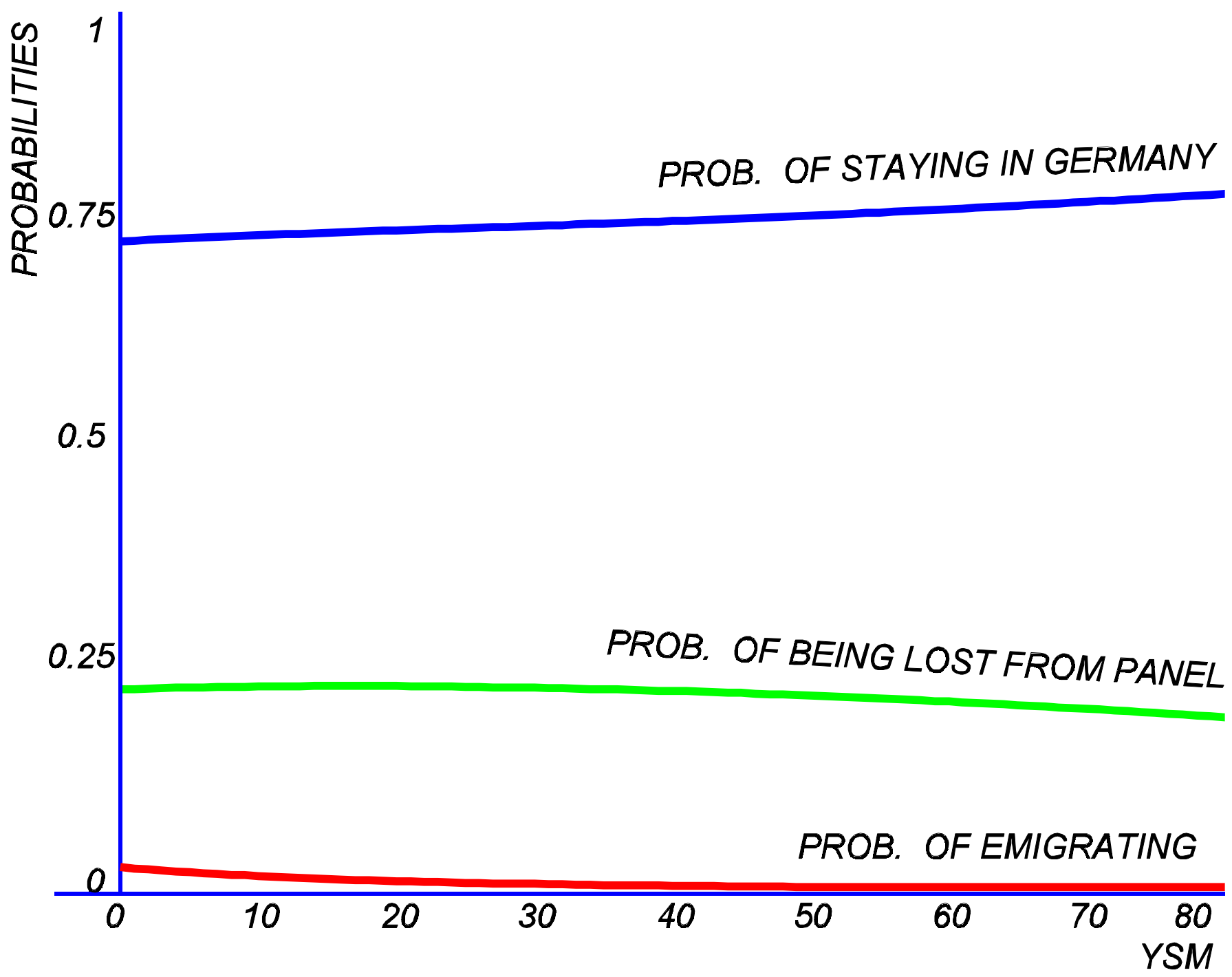

Figure 6: Probabilities of staying in Germany, of being lost to follow-up, and of emigrating with Years-sinceMigration; male guestworkers 1984-1997 
TABLE A5.2 MULTINOMIAL DISCRETE TIME EVENT HISTORY ANALYSIS OF THE LIKELIHOOD OF RETURN MIGRATION AMONG FEMALE IMMIGRANTS TO GERMANY 1984-1997. COMPARISON OUTCOME IS THE PROBABILITY TO STAY

\begin{tabular}{|c|c|c|c|c|}
\hline \multirow[b]{2}{*}{ Predictor Variables } & \multicolumn{2}{|c|}{ Probability of Return Migration } & \multicolumn{2}{|c|}{ Probability of Lost to Follow-Up } \\
\hline & $\mathrm{B}$ & SE & $\mathrm{B}$ & SE \\
\hline \multicolumn{5}{|l|}{ THEORETICAL VARIABLES } \\
\hline \multicolumn{5}{|l|}{ Human Capital } \\
\hline Home Country Schooling & 0.0174 & 0.0195 & $-0.0320^{*}$ & 0.0071 \\
\hline Time Since Migration & -0.0107 & 0.0167 & $0.0225^{\star}$ & 0.0071 \\
\hline Time Since Migration Squared & 0.00023 & 0.0003 & $-0.0005^{\star}$ & 0.0001 \\
\hline \multicolumn{5}{|l|}{ German Degree } \\
\hline No Degree & - & - & - & - \\
\hline Primary-secondary & 0.2567 & 0.1788 & 0.0364 & 0.0653 \\
\hline Technical & 0.1293 & 0.3155 & $0.3956^{*}$ & 0.0909 \\
\hline Abitur - Other & -0.0582 & 0.3631 & 0.1341 & 0.1495 \\
\hline German Vocational Training & -0.2666 & 0.2023 & -0.0897 & 0.0668 \\
\hline Fluent in German & -0.319 & 0.1760 & $0.1876^{\star}$ & 0.0584 \\
\hline \multicolumn{5}{|l|}{ Work Effort } \\
\hline Full Time & - & - & - & - \\
\hline Part Time, In Training & 0.1489 & 0.2374 & 0.0510 & 0.0762 \\
\hline \multicolumn{5}{|l|}{ Attachment to Employment } \\
\hline Unemployed & $0.7759^{\star}$ & 0.3099 & -0.1838 & 0.1151 \\
\hline Not Employed & $0.6551^{*}$ & 0.2819 & $-0.2089^{*}$ & 0.0954 \\
\hline \multicolumn{5}{|l|}{ Socioeconomic Achievement } \\
\hline Earnings & -0.00013 & 0.0004 & $-0.0004^{*}$ & 0.0001 \\
\hline Prestige & $-0.0126^{*}$ & 0.0051 & 0.0003 & 0.0019 \\
\hline \multicolumn{5}{|l|}{ Attachment to Germany } \\
\hline Spouse in Germany & $-0.2935^{\star}$ & 0.1491 & $-0.1935^{\star}$ & 0.0569 \\
\hline Children in Germany & $-0.272^{*}$ & 0.1112 & $0.3278^{*}$ & 0.0427 \\
\hline German Born & -0.199 & 0.2455 & $-0.2263^{*}$ & 0.0882 \\
\hline Own Home & -0.3067 & 0.2200 & -0.0573 & 0.0678 \\
\hline Feel German & -0.516 & 0.3626 & $-0.2170^{\star}$ & 0.0913 \\
\hline German Citizen & $-0.6446^{*}$ & 0.2763 & $0.2146^{*}$ & 0.0898 \\
\hline \multicolumn{5}{|l|}{ Attachment to Origin } \\
\hline Spouse in Home Country & $1.162^{*}$ & 0.3328 & 0.1631 & 0.1843 \\
\hline Children in Home Country & $0.4876^{\star}$ & 0.2006 & -0.0168 & 0.0884 \\
\hline Remitted & $0.3206^{*}$ & 0.1479 & -0.0547 & 0.0604 \\
\hline \multicolumn{5}{|l|}{ CONTROL VARIABLES } \\
\hline \multicolumn{5}{|l|}{ Demographic } \\
\hline \multicolumn{5}{|l|}{ Age } \\
\hline $16-18$ & - & - & - & - \\
\hline $19-24$ & 0.0623 & 0.2566 & -0.0340 & 0.0927 \\
\hline $25-64$ & -0.2105 & 0.2765 & $-0.2226^{\star}$ & 0.1018 \\
\hline $65+$ & 0.2885 & 0.3650 & $-1.1569^{*}$ & 0.2557 \\
\hline
\end{tabular}

Continued 
TABLE A5.2 Continued

\begin{tabular}{|c|c|c|c|c|}
\hline \multirow{2}{*}{ Predictor Variables } & \multicolumn{2}{|c|}{ Probability of Return Migration } & \multicolumn{2}{|c|}{ Probability of Lost to Follow-Up } \\
\hline & $\mathrm{B}$ & SE & $\mathrm{B}$ & SE \\
\hline \multicolumn{5}{|l|}{ CONTROL VARIABLES } \\
\hline \multicolumn{5}{|l|}{ National Origin } \\
\hline European Union & - & - & - & - \\
\hline Ex-Yugoslavia & $-1.00784^{*}$ & 0.1748 & 0.0504 & 0.0589 \\
\hline Turkey & $-0.756247^{\star}$ & 0.1348 & 0.0901 & 0.0517 \\
\hline \multicolumn{5}{|l|}{ Place of Residence } \\
\hline Berlin & - & - & - & - \\
\hline Schleswig-Holstein & -0.562553 & 0.5841 & 0.1449 & 0.1654 \\
\hline Hamburg & -0.281508 & 0.4415 & $-0.4729^{*}$ & 0.1525 \\
\hline Lower Saxony & -0.6276 & 0.3452 & -1.1137 & 0.1225 \\
\hline Bremen & 0.4374 & 0.5956 & $-0.2907^{\star}$ & 0.2418 \\
\hline North Rhein-Westfalia & -0.4686 & 0.2885 & $-0.7878^{*}$ & 0.0964 \\
\hline Hessen & -0.4789 & 0.3078 & $-0.2815^{\star}$ & 0.1006 \\
\hline Rheinland-Pfalz-Saarland & -0.5060 & 0.3507 & $-0.7792^{*}$ & 0.1268 \\
\hline Baden-Wurttemberg & $-0.7222^{*}$ & 0.2936 & $-1.0956^{\star}$ & 0.0977 \\
\hline Bavaria & -0.4488 & 0.3058 & $-0.8800^{\star}$ & 0.1035 \\
\hline \multicolumn{5}{|l|}{ Period } \\
\hline 1984 & - & - & - & - \\
\hline 1985 & $-0.9581^{*}$ & 0.2076 & $-0.2371^{*}$ & 0.0834 \\
\hline 1986 & $-1.1628^{*}$ & 0.2246 & $-0.3381^{*}$ & 0.0848 \\
\hline 1987 & $-0.7335^{\star}$ & 0.1954 & $-0.4349^{\star}$ & 0.0855 \\
\hline 1988 & $-1.3054^{\star}$ & 0.2353 & $-0.5333^{*}$ & 0.0870 \\
\hline 1989 & $-1.5234^{*}$ & 0.2566 & $-0.6206^{*}$ & 0.0877 \\
\hline 1990 & $-1.8898^{\star}$ & 0.2964 & $-0.7137^{*}$ & 0.0893 \\
\hline 1991 & $-1.7195^{\star}$ & 0.2823 & $-0.8452^{*}$ & 0.0913 \\
\hline 1992 & $-1.7587^{\star}$ & 0.2836 & $-0.9650^{*}$ & 0.0935 \\
\hline 1993 & $-1.5248^{*}$ & 0.2618 & $-1.1604^{*}$ & 0.0969 \\
\hline 1994 & $-1.6705^{\star}$ & 0.2740 & $-1.3810^{\star}$ & 0.1021 \\
\hline 1995 & $-1.4872^{\star}$ & 0.2613 & $-1.7470^{*}$ & 0.1134 \\
\hline $1996+$ & $-1.2402^{*}$ & 0.1988 & $-2.8627^{\star}$ & 0.1281 \\
\hline Intercept & -0.6044 & 0.5018 & $0.7494^{*}$ & 0.1828 \\
\hline \multirow{2}{*}{$\chi_{2}^{\text {Log Likelihood }}$} & \multicolumn{4}{|c|}{-9937.09} \\
\hline & \multicolumn{4}{|c|}{2284.18} \\
\hline Person Years & \multicolumn{4}{|c|}{16088} \\
\hline
\end{tabular}




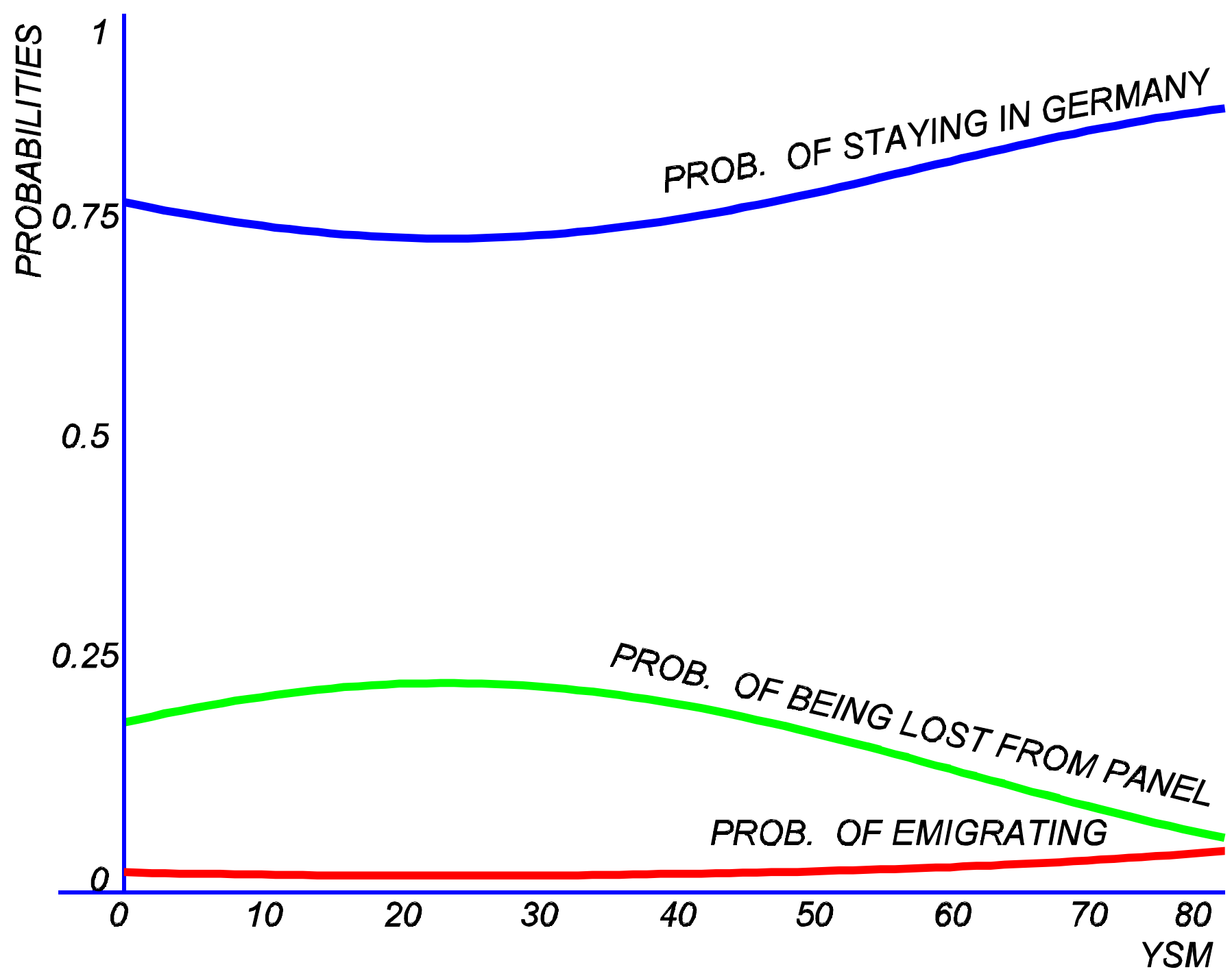

Figure 7: Probabilities of staying in Germany, of being lost to follow-up, and of emigrating with Years-sinceMigration; female guestworkers 1984-1997 


\begin{tabular}{|c|c|c|c|}
\hline Predictor Variables & Coefficient & St. Error & Odds Ratios \\
\hline \multicolumn{4}{|l|}{ THEORETICAL VARIABLES } \\
\hline \multicolumn{4}{|l|}{ Human Capital } \\
\hline Home Country Schooling & $0.0276^{\star}$ & 0.0140 & 1.028 \\
\hline Time Since Migration & $-0.0254^{*}$ & 0.0126 & 0.975 \\
\hline Time Since Migration Squared & $0.0004^{*}$ & 0.0003 & 1 \\
\hline \multicolumn{4}{|l|}{ German Degree } \\
\hline No Degree & - & - & - \\
\hline Primary-Secondary & 0.0261 & 0.1374 & 1.026 \\
\hline Technical & -0.0820 & 0.2327 & 0.921 \\
\hline Abitur & -0.2597 & 0.4733 & 0.771 \\
\hline Other & -0.0611 & 0.2618 & 0.941 \\
\hline German Vocational Training & -0.0513 & 0.1305 & 0.95 \\
\hline Fluent in German & $-0.4094^{*}$ & 0.1305 & 0.664 \\
\hline \multicolumn{4}{|l|}{ Work Effort } \\
\hline Full Time & - & - & . \\
\hline Part Time & 0.0511 & 0.2384 & 1.052 \\
\hline In Training & -0.1310 & 0.3282 & 0.877 \\
\hline Attachment to Employment & 0.5258 & 0.3416 & 1.692 \\
\hline Registered as Unemployed & $0.7743^{*}$ & 0.2072 & 2.169 \\
\hline Not Employed & $0.8039^{*}$ & 0.1924 & 2.234 \\
\hline \multicolumn{4}{|l|}{ Socioeconomic Achievement } \\
\hline Weekly Wages & -0.0004 & 0.0002 & 1 \\
\hline Prestige & $-0.0088^{*}$ & 0.0039 & 0.991 \\
\hline \multicolumn{4}{|l|}{ Attachment to Germany } \\
\hline Spouse in Germany & $-0.2541^{*}$ & 0.1094 & 0.776 \\
\hline Children in Germany & $-0.3559^{*}$ & 0.0806 & 0.701 \\
\hline German Born & -0.1177 & 0.1933 & 0.889 \\
\hline Own Home & $-0.3582^{*}$ & 0.1576 & 0.699 \\
\hline Feel German & $-0.6081^{*}$ & 0.2913 & 0.544 \\
\hline German Citizen & $-0.7919^{\star}$ & 0.2216 & 0.453 \\
\hline \multicolumn{4}{|l|}{ Attachment to Origin } \\
\hline Spouse in Home Country & $0.9686^{*}$ & 0.1741 & 2.634 \\
\hline Children in Home Country & $0.3797^{*}$ & 0.1348 & 1.462 \\
\hline Remitted & $0.3198^{*}$ & 0.0961 & 1.377 \\
\hline \multicolumn{4}{|l|}{ CONTROL VARIABLES } \\
\hline \multicolumn{4}{|l|}{ Demographic } \\
\hline \multicolumn{4}{|l|}{ Age } \\
\hline $16-18$ & - & - & - \\
\hline $19-24$ & 0.2618 & 0.2064 & 1.299 \\
\hline $25-64$ & 0.2501 & 0.2198 & 1.284 \\
\hline $65+$ & $0.8916^{*}$ & 0.2729 & 2.439 \\
\hline Male & 0.0270 & 0.0854 & 1.027 \\
\hline \multicolumn{4}{|l|}{ National Origin } \\
\hline European Ǔnion & - & - & - \\
\hline Ex-Yugoslavia & $-1.0886^{*}$ & 0.1249 & 0.337 \\
\hline Turk & $-0.8529^{*}$ & 0.0937 & 0.426 \\
\hline \multicolumn{4}{|l|}{ Place of Residence } \\
\hline Berlin & - & - & - \\
\hline Schleswig-Holstein & -0.3342 & 0.3966 & 0.716 \\
\hline Hamburg & -0.1725 & 0.3154 & 0.842 \\
\hline Lower Saxony & -0.1928 & 0.2444 & 0.825 \\
\hline Bremen & 0.7743 & 0.4061 & 2.169 \\
\hline North Rhein-Westfalia & -0.1584 & 0.2089 & 0.854 \\
\hline Hessen & -0.2587 & 0.2233 & 0.772 \\
\hline Rheinland-Pfalz-Saarland & -0.1650 & 0.2546 & 0.848 \\
\hline Baden-Wurttemberg & -0.2563 & 0.2118 & 0.774 \\
\hline Bavaria & -0.1263 & 0.2234 & 0.881 \\
\hline
\end{tabular}


TABLE A6.1. Continues

\begin{tabular}{lrrr}
\hline Predictor Variables & Coefficient & St. Error & Odds Ratios \\
\hline Period & - & - & - \\
1984 & $-0.8558^{*}$ & 0.1491 & 0.425 \\
1985 & $-0.9796^{*}$ & 0.1595 & 0.375 \\
1986 & $-0.4541^{*}$ & 0.1369 & 0.635 \\
1987 & $-0.8744^{*}$ & 0.1598 & 0.417 \\
1988 & $-1.0793^{*}$ & 0.1783 & 0.34 \\
1989 & $-1.3732^{*}$ & 0.2016 & 0.253 \\
1990 & $-1.4138^{*}$ & 0.2111 & 0.243 \\
1991 & $-1.3226^{*}$ & 0.2046 & 0.266 \\
1992 & $-0.8278^{*}$ & 0.1752 & 0.437 \\
1993 & $-1.1202^{*}$ & 0.1979 & 0.326 \\
1994 & $-0.8661^{*}$ & 0.1873 & 0.421 \\
1995 & $-1.3952^{*}$ & 0.2289 & 0.248 \\
1996 & 0.0104 & 0.1552 & 1.01 \\
1997 & & & \\
Intercept & $-1.9433^{*}$ & 0.3668 & \\
$\chi_{2}$ Likelihood & & -3436.60 & \\
Person Years & & 808.48 & \\
* $p<0.05$ & & 33493 &
\end{tabular}




\begin{tabular}{|c|c|c|c|c|c|c|}
\hline Predictor Variables & Coefficient & St. Error & OddsRatios & Coefficient & St. Error & OddsRatios \\
\hline \multicolumn{7}{|l|}{$\begin{array}{l}\text { THEORETICAL VARIABLES } \\
\text { Human Capital }\end{array}$} \\
\hline Home Country Schooling & 0.0213 & 0.0204 & 1.022 & 0.0189 & 0.0196 & 1.019 \\
\hline Time Since Migration & -0.0429 & 0.0228 & 0.958 & -0.0187 & 0.0166 & 0.982 \\
\hline Time Since Migration Squared & 0.0002 & 0.00056 & 1 & 0.0003 & 0.00032 & 1 \\
\hline \multicolumn{7}{|l|}{ German Degree } \\
\hline $\begin{array}{l}\text { No Degree } \\
\text { Primary-Secondary }\end{array}$ & -0.3443 & $0.2187^{-}$ & $0.709^{-}$ & $0.2451^{-}$ & $0.1778^{-}$ & $1.278^{-}$ \\
\hline Technical & -0.2937 & 0.3493 & 0.745 & 0.0422 & 0.3146 & 1.043 \\
\hline Other & -0.1572 & 0.3043 & 0.855 & -0.1296 & 0.3645 & 0.878 \\
\hline German Vocational Training & 0.0692 & 0.1734 & 1.072 & -0.2561 & 0.2018 & 0.774 \\
\hline Fluent in German & $-0.5033^{*}$ & 0.1938 & 0.605 & $-0.4146^{\star}$ & 0.1773 & 0.661 \\
\hline \multicolumn{7}{|l|}{ Work Effort } \\
\hline Full Time & - & - & - & - & - & - \\
\hline Part Time & -0.0852 & 0.4123 & 0.918 & 0.1240 & 0.2345 & 1.132 \\
\hline \multicolumn{7}{|l|}{ Attachment to Employment } \\
\hline Registered as Unemployed & $0.8786^{*}$ & 0.2783 & 2.408 & $0.8092^{*}$ & 0.3026 & 2.246 \\
\hline Not Employed & $1.4028^{*}$ & 0.2747 & 4.066 & $0.7064^{*}$ & 0.2742 & 2.027 \\
\hline \multicolumn{7}{|l|}{ Socioeconomic Achievement } \\
\hline Weekly Wages & -0.0004 & 0.000299 & 1 & -0.0000 & 0.00039 & 1 \\
\hline Prestige & 0.0070 & 0.00627 & 1.007 & $-0.0125^{\star}$ & 0.00505 & 0.988 \\
\hline \multicolumn{7}{|l|}{ Attachment to Germany } \\
\hline Spouse in Germany & -0.2971 & 0.1668 & 0.743 & -0.2377 & 0.1482 & 0.788 \\
\hline Children in Germany & $-0.2693^{*}$ & 0.1207 & 0.764 & $-0.3651^{*}$ & 0.1108 & 0.694 \\
\hline German Born & -0.2691 & 0.3256 & 0.764 & -0.0634 & 0.2451 & 0.939 \\
\hline Own Home & -0.4275 & 0.2282 & 0.652 & -0.3099 & 0.2198 & 0.734 \\
\hline Feel German & -0.9295 & 0.5178 & 0.395 & -0.4462 & 0.3605 & 0.64 \\
\hline German Citizen & $-0.9161^{*}$ & 0.3881 & 0.4 & $-0.7448^{*}$ & 0.2759 & 0.475 \\
\hline \multicolumn{7}{|l|}{ Attachment to Origin } \\
\hline Spouse in Home Country & $1.0256^{\star}$ & 0.2319 & 2.789 & $1.0397^{*}$ & 0.3292 & 2.828 \\
\hline Children in Home Country & 0.3296 & 0.1869 & 1.39 & 0.4872 & 0.1986 & 1.628 \\
\hline Remitted & $0.2590^{*}$ & 0.1268 & 1.296 & $0.3585^{\star}$ & 0.1472 & 1.431 \\
\hline \multicolumn{7}{|l|}{ CONTROL VARIABLES } \\
\hline \multicolumn{7}{|l|}{ Demographic } \\
\hline \multicolumn{7}{|l|}{ Age } \\
\hline $16-18$ & - & - & - & - & - & - \\
\hline $19-24$ & $0.7403^{*}$ & 0.3594 & 2.097 & 0.1076 & 0.2548 & 1.114 \\
\hline $25-64$ & $1.0144^{*}$ & 0.3779 & 2.758 & -0.0827 & 0.2747 & 0.921 \\
\hline $65+$ & $1.4607^{*}$ & 0.4453 & 4.309 & 0.5258 & 0.3653 & 1.692 \\
\hline \multicolumn{7}{|l|}{ National Origin } \\
\hline European Union & - & - & - & - & - & - \\
\hline Ex-Yugoslavia & $-1.1708^{*}$ & 0.1812 & 0.31 & $-1.0392^{*}$ & 0.1743 & 0.354 \\
\hline Turk & $-0.8956^{*}$ & 0.1324 & 0.408 & $-0.8071^{\star}$ & 0.1343 & 0.446 \\
\hline \multicolumn{7}{|l|}{ Place of Residence } \\
\hline Berlin & - & - & - & - & - & - \\
\hline Schleswig-Holstein & 0.0952 & 0.5514 & 1.100 & -0.6289 & 0.5798 & \\
\hline Hamburg & -0.1259 & 0.4601 & 0.882 & -0.0906 & 0.439 & 0.913 \\
\hline Lower Saxony & 0.0110 & 0.3549 & 1.011 & -0.2605 & 0.3428 & 0.771 \\
\hline Bremen & $1.1560^{*}$ & 0.567 & 3.177 & 0.5485 & 0.5915 & 1.731 \\
\hline North Rhein-Westfalia & -0.0088 & 0.309 & 0.991 & -0.1785 & 0.2863 & 0.837 \\
\hline Hessen & -0.0511 & 0.3317 & 0.95 & -0.3533 & 0.3052 & 0.702 \\
\hline Rheinland-Pfalz-Saarland & 0.0771 & 0.3762 & 1.08 & -0.2456 & 0.3484 & 0.782 \\
\hline Baden-Wurttemberg & -0.0637 & 0.3122 & 0.938 & -0.3621 & 0.2916 & 0.696 \\
\hline Bavaria & -0.0108 & 0.334 & 0.989 & -0.1356 & 0.3037 & 0.873 \\
\hline
\end{tabular}




\begin{tabular}{lrrrrrr}
\hline Predictor Variables & Coefficient & St. Error & OddsRatios & Coefficient & St. Error & OddsRatios \\
\hline Period & & & - & & & - \\
1984 & - & - & - & - & - \\
1985 & $-0.8452^{*}$ & 0.2184 & 0.429 & $-0.8611^{*}$ & 0.2048 & 0.423 \\
1986 & $-0.9315^{*}$ & 0.2312 & 0.394 & $-1.0264^{*}$ & 0.222 & 0.358 \\
1987 & -0.3179 & 0.1965 & 0.728 & $-0.5614^{*}$ & 0.1925 & 0.57 \\
1988 & $-0.6067^{*}$ & 0.2225 & 0.545 & $-1.1007^{*}$ & 0.233 & 0.333 \\
1989 & $-0.8354^{*}$ & 0.252 & 0.434 & $-1.2897^{*}$ & 0.2545 & 0.275 \\
1990 & $-1.0921^{*}$ & 0.2794 & 0.336 & $-1.6285^{*}$ & 0.2945 & 0.196 \\
1991 & $-1.3843^{*}$ & 0.3222 & 0.25 & $-1.4180^{*}$ & 0.2804 & 0.242 \\
1992 & $-1.1723^{*}$ & 0.3 & 0.31 & $-1.4244^{*}$ & 0.2818 & 0.241 \\
1993 & $-0.4831^{*}$ & 0.2435 & 0.617 & $-1.1474^{*}$ & 0.2599 & 0.317 \\
1994 & $-0.9324^{*}$ & 0.2906 & 0.394 & $-1.2502^{*}$ & 0.2722 & 0.286 \\
1995 & $-0.6575^{*}$ & 0.2741 & 0.518 & $-1.0154^{*}$ & 0.2595 & 0.362 \\
1996 & $-1.0212^{*}$ & 0.3181 & 0.36 & $-1.7018^{*}$ & 0.3352 & 0.182 \\
1997 & 0.2860 & 0.2306 & 1.331 & -0.1400 & 0.2126 & 0.869 \\
Intercept & & & & & & \\
Log Likelihood & $-3.0669^{*}$ & 0.5697 & & $-1.5087^{*}$ & 0.4942 & \\
Person Years & & -1674.358 & & & -1728.964 &
\end{tabular}

${ }^{*} p<0.05$ 
ENTIRE GUESTWORKER POPULATION IN 1995

PARAMETERS COEFFICIENTS (t-ratio)

\begin{tabular}{|c|c|c|c|c|c|c|}
\hline & (1) & (2) & (3) & (4) & (5) & (6) \\
\hline \multirow[t]{2}{*}{ INTERCEPT } & $4.094^{*}$ & $4.1636^{\star}$ & $3.1571^{*}$ & $4.0146^{*}$ & $4.0912^{*}$ & $3.1027^{*}$ \\
\hline & $(25.24)$ & $(24.98)$ & $(19.71)$ & $(23.99)$ & (23.72) & (18.82) \\
\hline \multirow[t]{2}{*}{ AGE } & $0.1069^{\star}$ & $0.1032^{*}$ & $0.0976^{*}$ & $0.1120^{*}$ & $0.1084^{*}$ & $0.1019^{*}$ \\
\hline & (11.80) & (10.59) & $(11.34)$ & $(11.89)$ & (10.65) & (11.35) \\
\hline \multirow[t]{2}{*}{$\mathrm{AGE}^{2}$} & $-0.0013^{*}$ & $-0.0013^{*}$ & $-0.0011^{*}$ & $-0.0013^{*}$ & $-0.0013^{*}$ & $-0.0012^{\star}$ \\
\hline & $(-11.62)$ & $(-10.75)$ & $(-11.27)$ & $(-11.74)$ & $(-10.82)$ & $(-11.23)$ \\
\hline \multirow[t]{2}{*}{ YSM } & 0.0062 & 0.0072 & 0.0053 & 0.0061 & 0.0070 & 0.0053 \\
\hline & $(1.14)$ & (1.33) & $(1.11)$ & $(1.12)$ & $(1.27)$ & $(1.11)$ \\
\hline \multirow[t]{2}{*}{$\mathrm{YSM}^{2}$} & -0.00002 & -0.00002 & -0.0000 & -0.0000 & 0.0000 & -0.0000 \\
\hline & $(-0.16)$ & $(-0.19)$ & $(-0.32)$ & $(-0.05)$ & $(-0.05)$ & $(-0.30)$ \\
\hline \multirow[t]{2}{*}{ SEX } & $0.3949^{*}$ & $0.3973^{*}$ & $0.2195^{\star}$ & $0.3848^{*}$ & $0.3870^{*}$ & $0.2110^{*}$ \\
\hline & $(13.97)$ & $(14.10)$ & $(8.54)$ & $(13.37)$ & $(13.49)$ & (8.07) \\
\hline \multirow[t]{2}{*}{ PRIMARY-SECONDARY } & 0.0391 & 0.0431 & 0.0175 & 0.0470 & 0.0495 & 0.0232 \\
\hline & $(0.89)$ & $(0.99)$ & $(0.46)$ & $(1.05)$ & $(1.11)$ & $(0.60)$ \\
\hline \multirow[t]{2}{*}{ TECHNICAL DEGREE } & 0.0290 & 0.0265 & 0.0031 & 0.0278 & 0.0247 & -0.0005 \\
\hline & $(0.55)$ & $(0.50)$ & $(0.07)$ & $(0.52)$ & $(0.46)$ & $(-0.01)$ \\
\hline \multirow[t]{2}{*}{ ABITUR } & 0.0357 & 0.0412 & -0.0227 & 0.0020 & -0.0010 & -0.0423 \\
\hline & $(0.31)$ & $(0.36)$ & $(-0.23)$ & $(0.02)$ & $(-0.01)$ & $(-0.41)$ \\
\hline \multirow[t]{2}{*}{ OTHER DEGREE IN G } & -0.0674 & -0.0617 & -0.0911 & -0.0532 & -0.0563 & -0.0689 \\
\hline & $(-1.01)$ & $(-0.92)$ & $(-1.57)$ & $(-0.78)$ & $(-0.81)$ & $(-1.15)$ \\
\hline \multirow[t]{2}{*}{ VOC'L TRAINING IN G } & $0.1260^{*}$ & $0.1196^{\star}$ & $0.0961^{*}$ & $0.1216^{\star}$ & $0.1181^{*}$ & $0.0903^{*}$ \\
\hline & $(3.51)$ & $(3.34)$ & $(3.11)$ & (3.33) & (3.23) & $(2.87)$ \\
\hline \multirow[t]{2}{*}{ EDUHOME } & $0.0126^{*}$ & $0.0132^{*}$ & 0.0042 & $0.0152^{*}$ & $0.0157^{*}$ & 0.0053 \\
\hline & $(2.20)$ & $(2.30)$ & $(0.84)$ & $(2.59)$ & $(2.68)$ & $(1.04)$ \\
\hline \multirow[t]{2}{*}{ SPKGFLU } & -0.0144 & -0.0192 & -0.0529 & -0.01367 & -0.0199 & -0.0484 \\
\hline & $(-0.41)$ & $(-0.54)$ & $(-1.69)$ & $(-0.38)$ & $(-0.55)$ & $(-1.51)$ \\
\hline \multirow[t]{2}{*}{ MAR_SPOUSE IN G } & & $0.0996^{\star}$ & $0.1181^{*}$ & & $0.0863^{*}$ & $0.1026^{*}$ \\
\hline & & $(2.65)$ & $(3.60)$ & & $(2.25)$ & (3.06) \\
\hline \multirow[t]{2}{*}{ MAR NO SPOUSE IN G } & & 0.1884 & 0.1464 & & 0.1339 & 0.1011 \\
\hline & & $(1.55)$ & (1.39) & & $(0.96)$ & $(0.84)$ \\
\hline \multirow[t]{2}{*}{ KIDS IN HH } & & $-0.0959^{\star}$ & $-0.0724^{\star}$ & & $-0.0963^{*}$ & $-0.0675^{\star}$ \\
\hline & & $(-3.25)$ & $(-2.81)$ & & $(-3.21)$ & $(-2.57)$ \\
\hline \multirow[t]{2}{*}{ KIDS NATIVE } & & -0.1083 & 0.0075 & & -0.0156 & 0.0561 \\
\hline & & $(-1.06)$ & $(0.09)$ & & $(-0.14)$ & $(0.59)$ \\
\hline \multirow[t]{2}{*}{ HOURS WORKING } & & & $0.0243^{*}$ & & & $0.0244^{*}$ \\
\hline & & & (19.33) & & & $(19.14)$ \\
\hline \multirow[t]{2}{*}{ TREIMAN PRESTIGE } & & & $0.0094^{*}$ & & & $0.0088^{*}$ \\
\hline & & & $(7.05)$ & & & $(6.48)$ \\
\hline \multirow[t]{2}{*}{ GERMAN CITIZEN } & & & -0.0282 & & & -0.0135 \\
\hline & & & $(-0.66)$ & & & $(-0.31)$ \\
\hline \multirow[t]{2}{*}{ EX-YUGOSLAV } & & & 0.0462 & & & 0.0595 \\
\hline & & & $(1.41)$ & & & $(1.77)$ \\
\hline \multirow[t]{2}{*}{ TURK } & & & -0.0110 & & & -0.0064 \\
\hline & & & $(-0.32)$ & & & $(-0.18)$ \\
\hline
\end{tabular}

GUESTWORKERS WHO DID NOT EMIGRATE IN 1995 COEFFICIENTS

(t-ratio)$$
\text { (5) }
$$

3.1027

0.1019

(11.35)

(-11.23)

0.0053

$(-0.30)$

0.2110

0.0232

$(-0.01)$

.0423

$-0.0689$

$-1.15$

0.0903

0.0053

$-0.0484$

0.1026

$-0.0675^{\star}$

57)

0244

0.0088

(6.48)

$-0.0135$

$(-0.31)$

0.0595

$-0.0064$

$(-0.18)$ 


\begin{tabular}{|c|c|c|c|c|c|c|}
\hline & \multicolumn{3}{|c|}{$\begin{array}{l}\text { ENTIRE GUESTWORKER } \\
\text { POPULATION IN } 1995\end{array}$} & \multicolumn{3}{|c|}{$\begin{array}{c}\text { GUESTWORKERS WHO DID NOT } \\
\text { EMIGRATE IN } 1995\end{array}$} \\
\hline $\mathrm{R}^{2}$ & 0.2826 & 0.2915 & 0.4765 & 0.2833 & 0.2908 & 0.4760 \\
\hline F statistic & 43.42 & 33.92 & 56.96 & 41.63 & 32.29 & 54.29 \\
\hline Mean of Ln Weekly Wages & & 6.58343 & & & 6.58383 & \\
\hline Number of Obs & & 1336 & & & 1277 & \\
\hline
\end{tabular}

Note:* indicates significance at the 5 per cent level in two-tailed test $(p<0.05)$ 


\begin{tabular}{|c|c|c|}
\hline & $\begin{array}{l}\text { ENTIRE GUESTWORKER } \\
\text { POPULATION IN } 1995\end{array}$ & $\begin{array}{l}\text { GUESTWORKERS WHO DID } \\
\text { NOT EMIGRATE IN } 1995\end{array}$ \\
\hline PREDICTOR VARIABLES & $\begin{array}{c}\text { COEFFICIENTS } \\
\text { (St. Error) }\end{array}$ & $\begin{array}{c}\text { COEFFICIENTS } \\
\text { (St. Error) }\end{array}$ \\
\hline INTERCEPT & $\begin{array}{l}-3.1687^{*} \\
(0.3260)\end{array}$ & $\begin{array}{l}-3.1421^{*} \\
(0.3395)\end{array}$ \\
\hline AGE & $\begin{array}{l}0.1797^{*} \\
(0.0186)\end{array}$ & $\begin{array}{l}0.1827^{*} \\
(0.0196)\end{array}$ \\
\hline $\mathrm{AGE}^{2}$ & $\begin{array}{l}-0.0025^{*} \\
(0.0002)\end{array}$ & $\begin{array}{l}-0.0026^{*} \\
(0.0002)\end{array}$ \\
\hline YSM & $\begin{array}{c}0.0180 \\
(0.0110)\end{array}$ & $\begin{array}{c}0.0151 \\
(0.0113)\end{array}$ \\
\hline $\mathrm{YSM}^{2}$ & $\begin{array}{l}-0.0000 \\
(0.0002)\end{array}$ & $\begin{array}{c}0.0000 \\
(0.0002)\end{array}$ \\
\hline SEX & $\begin{array}{l}0.5612^{*} \\
(0.0631)\end{array}$ & $\begin{array}{l}0.5690^{\star} \\
(0.0654)\end{array}$ \\
\hline $\begin{array}{l}\text { PRIMARY-SECONDARY IN } \\
\text { GERMANY }\end{array}$ & $\begin{array}{l}0.2868^{*} \\
(0.0990)\end{array}$ & $\begin{array}{l}0.3063^{*} \\
(0.1015)\end{array}$ \\
\hline TECHNICAL DEGREE IN G & $\begin{array}{l}0.2664^{*} \\
(0.1222)\end{array}$ & $\begin{array}{l}0.3400^{*} \\
(0.1259)\end{array}$ \\
\hline ABITUR IN GERMANY & $\begin{array}{c}0.0481 \\
(0.2656)\end{array}$ & $\begin{array}{c}0.0319 \\
(0.2775)\end{array}$ \\
\hline OTHER DEGREE IN G & $\begin{array}{c}0.0179 \\
(0.1579)\end{array}$ & $\begin{array}{c}0.0193 \\
(0.1674)\end{array}$ \\
\hline VOC'L TRAINING IN G & $\begin{array}{c}0.0206 \\
(0.0879)\end{array}$ & $\begin{array}{c}0.0332 \\
(0.0907)\end{array}$ \\
\hline EDU IN HOME COUNTRY & $\begin{array}{l}0.0327^{*} \\
(0.0117)\end{array}$ & $\begin{array}{l}0.0335^{\star} \\
(0.0123)\end{array}$ \\
\hline SPEAK GERMAN FLUENTLY & $\begin{array}{l}0.1887^{\star} \\
(0.0841)\end{array}$ & $\begin{array}{c}0.1403 \\
(0.0866)\end{array}$ \\
\hline MARRIED-SPOUSE IN G & $\begin{array}{l}-0.0713 \\
(0.0896)\end{array}$ & $\begin{array}{l}-0.0920 \\
(0.0929)\end{array}$ \\
\hline MARRIED-NO SPOUSE IN G & $\begin{array}{c}0.1478 \\
(0.2795)\end{array}$ & $\begin{array}{c}0.3231 \\
(0.3570)\end{array}$ \\
\hline KIDS IN HOUSEHOLD & $\begin{array}{l}-0.1148 \\
(0.0658)\end{array}$ & $\begin{array}{l}-0.1288 \\
(0.0681)\end{array}$ \\
\hline KIDS IN NATIVE COUNTRY & $\begin{array}{c}0.4221 \\
(0.3084)\end{array}$ & $\begin{array}{c}0.2493 \\
(0.3214)\end{array}$ \\
\hline OWN DWELLING & $\begin{array}{l}0.2335^{\star} \\
(0.0907)\end{array}$ & $\begin{array}{l}0.2044^{*} \\
(0.0930)\end{array}$ \\
\hline REMIT & $\begin{array}{l}0.5381^{*} \\
(0.0861)\end{array}$ & $\begin{array}{l}0.5661^{*} \\
(0.0912)\end{array}$ \\
\hline GERMAN CITIZEN & $\begin{array}{l}-0.2431^{*} \\
(0.1119)\end{array}$ & $\begin{array}{l}-0.2834^{*} \\
(0.1152)\end{array}$ \\
\hline EX-YUGOSLAV & $\begin{array}{c}0.0154 \\
(0.0957)\end{array}$ & $\begin{array}{l}-0.0113 \\
(0.1012)\end{array}$ \\
\hline TURK & $\begin{array}{l}-0.3258^{*} \\
(0.0822)\end{array}$ & $\begin{array}{l}-0.3404^{*} \\
(0.0860)\end{array}$ \\
\hline LOG LIKELIHOOD & -1153.233 & -1068.282 \\
\hline$\chi_{2}$ & 536.4579 & 479.2023 \\
\hline $\begin{array}{l}\text { NUMBER OF OBSERVATIONS } \\
{ }^{*} \mathrm{p}<0.05\end{array}$ & 2142 & 1996 \\
\hline
\end{tabular}


ENTIRE GUESTWORKER GUESTWORKERS WHO DID POPULATION IN $1995 \quad$ NOT EMIGRATE IN 1995 COEFFICIENTS COEFFICIENTS

PREDICTOR VARIABLES

INTERCEPT

AGE

$\mathrm{AGE}^{2}$

YSM

$\mathrm{YSM}^{2}$

SEX

PRIMARY-SECONDARY DEGREE IN G

TECHNICAL DEGREE IN G

ABITUR IN GERMANY

OTHER DEGREE IN GERMANY

VOC'L TRAINING IN G

EDU IN HOME COUNTRY

SPEAK GERMAN FLUENTLY

HOURS WORKING PER WEEK

TREIMAN PRESTIGE SCORE

GERMAN CITIZEN

EX-YUGOSLAV

TURK

$\lambda$

MEAN LN WAGE

(STD. DEVIATION OF WAGE)

LOG LIKELIHOOD

$\mathrm{R}^{2}$

F STATISTIC

NUMBER OF OBSERVATIONS

${ }^{*} p<0.05$
(St. Error)

$3.8710^{*}$

$(0.3060)$

$0.0750^{*}$

$(0.0128)$

$-0.0008^{*}$

$(0.0002)$

0.0017

$(0.0053)$

$-0.0000$

(0.0001)

$0.1391^{*}$

(0.0402)

$-0.0176$

$(0.0427)$

$-0.0199$

$(0.0526)$

$-0.0272$

(0.1090)

$-0.1055$

(0.0626)

$0.0966^{*}$

(0.0336)

$-0.0018$

(0.0058)

$-0.0769^{*}$

$(0.0355)$

$0.0234^{*}$

$(0.0013)$

$0.0089^{*}$

$(0.0013)$

$-0.0092$

(0.0474)

$-0.0308$

$(0.0384)$

$0.0972^{*}$

$(0.0384)$

$-0.2995^{*}$

(0.1028)

6.5903

0.57695

$-734.3018$

0.4608

$F[18,1310]=62.19$

1336
(St. Error)

3.7917*

(0.3041)

$0.0797^{*}$

$(0.0129)$

$-0.0009^{*}$

(0.0002)

0.0024

$(0.0053)$

$-0.0000$

(0.0001)

$0.1323^{*}$

(0.0405)

$-0.0115$

$(0.0435)$

$-0.0325$

$(0.0538)$

$-0.0434$

(0.1107)

$-0.0782$

$(0.0640)$

$0.0882^{*}$

$(0.0340)$

$-0.0004$

(0.0059)

$-0.0645$

$(0.0354)$

$0.0235^{*}$

$(0.0013)$

$0.0082^{*}$

(0.0014)

0.0109

(0.0480)

$-0.0260$

(0.0392)

$0.1090^{*}$

(0.0391)

$-0.2942^{*}$

(0.1030)

6.59099

0.5736

$-693.8621$

0.4608

$F[18,1251]=59.40$

1277 


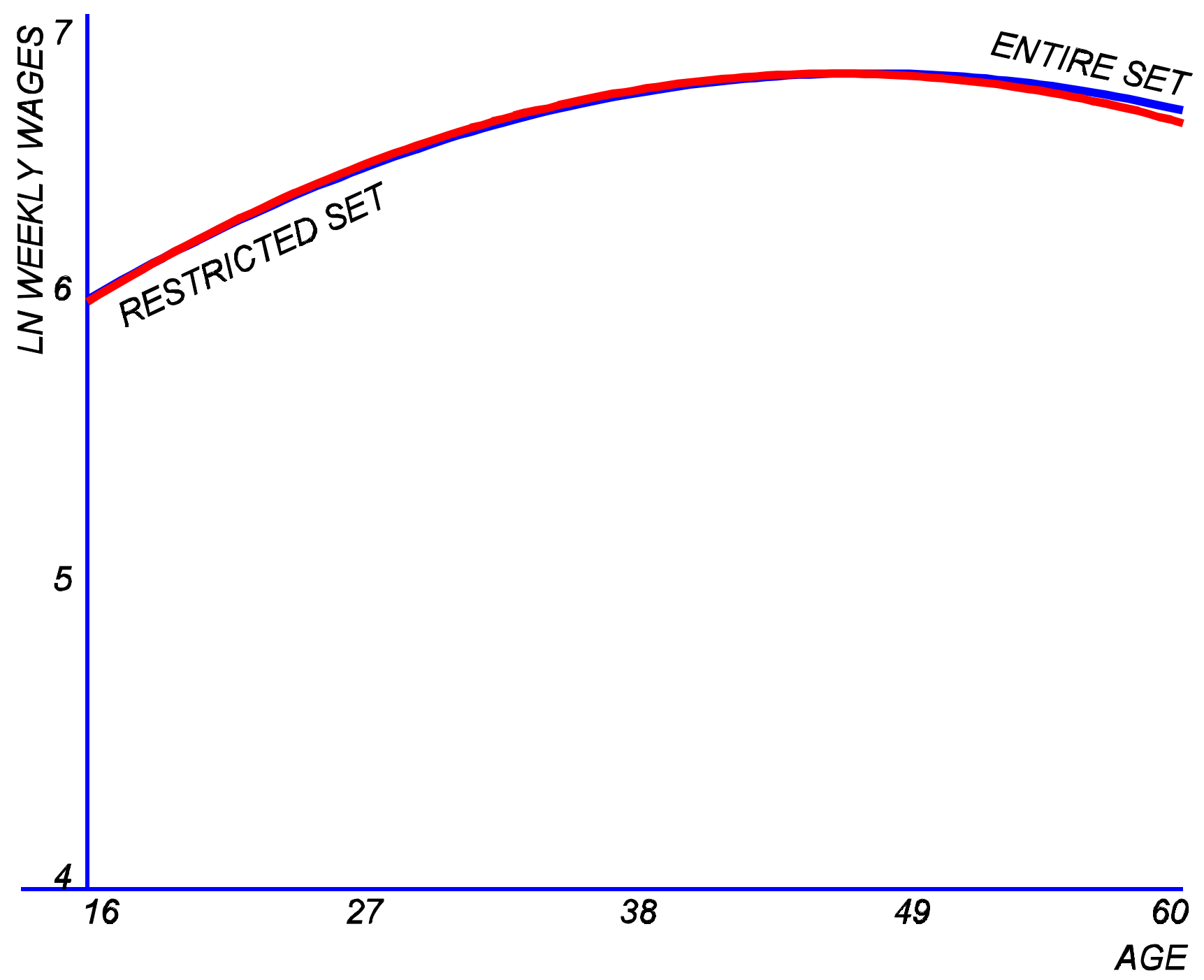

Figure 8: Age/Earnings Profiles of Guestworkers in Germany in 1995 


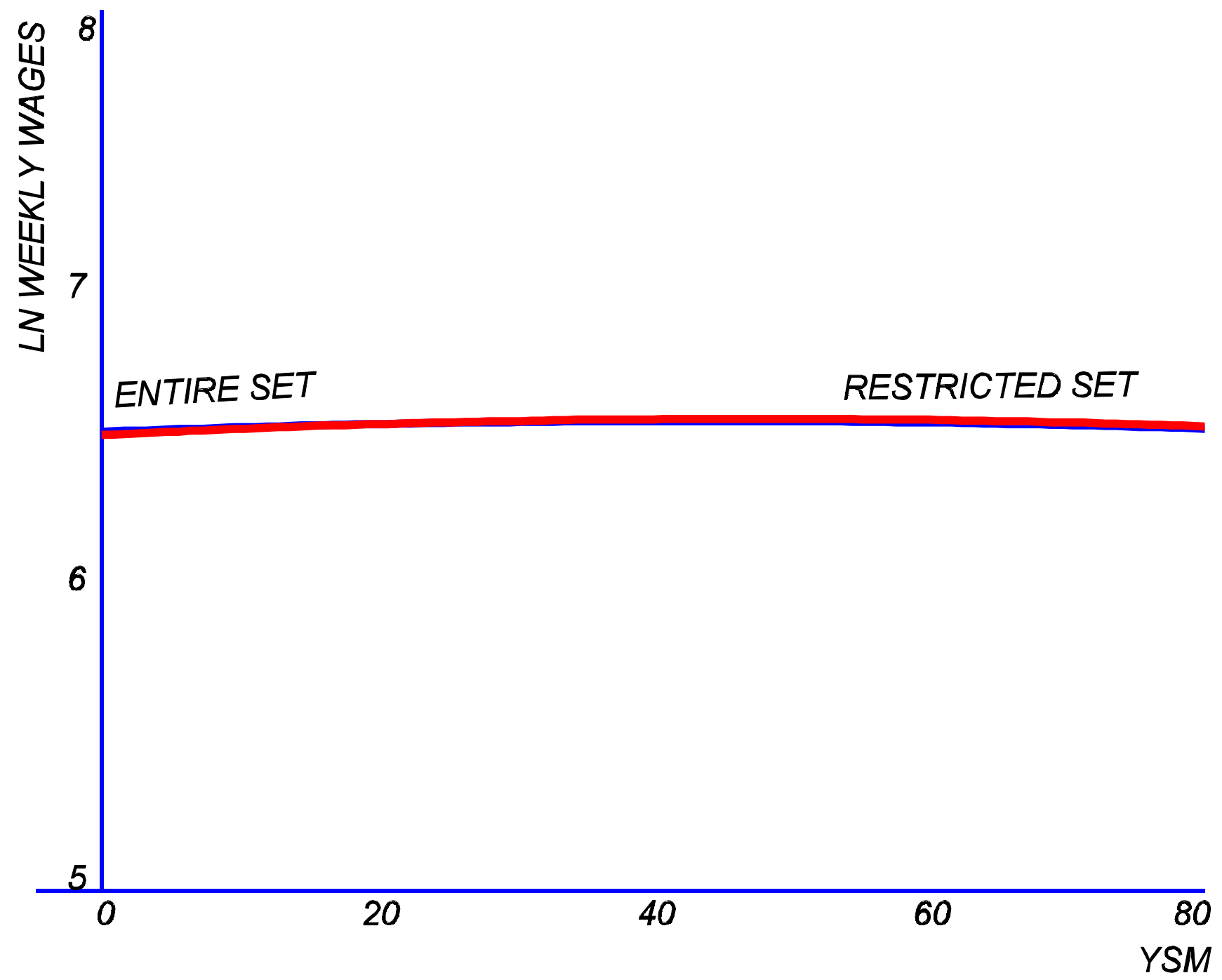

Figure 9: YSM/Earnings Profiles of Guestworkers in Germany in 1995 


\section{REFERENCES}

Allison, Paul David, (1984) Event History Analysis. Regression for Longitudinal Event

Data, Quantitative Applications in the Social Sciences Series, Vol. 46. Sage Publications. Barrett, Alan, and Trace, Fergal, (Summer 1998) "Who Is Coming Back? The Educational Profile of Returning Migrants in the 1990s," Irish Banking Review, 38-51.

Bauer, Thomas, and Gang, Ira N., (April 1998) “Temporary Migrants from Egypt: How Long Do They Stay Abroad?" Discussion Paper No. 3, IZA, Bonn, Germany.

Becker, Gary S., (1975) Human Capital, The University of Chicago Press, Chicago.

Bohning, Wolf R., (May 1981) "Estimating the Propensity of Guestworkers to Leave," Monthly Labor Review, Communications, Vol. 104, No. 5, 37-40.

Borjas, George J.,(January 1989) "Immigrant and Emigrant Earnings: A Longitudinal Study," Economic Inquiry, Vol. 27, No. 1, 21-37.

(September 1987) "Self-Selection and the Earnings of Immigrants," The

American Economic Review, Vol. 77, No. 4, 531-553.

(October 1985) "Assimilation, Changes in Cohort Quality, and the

Earnings of Immigrants," Journal of Labor Economics, Vol. 3, No. 4, 463-489.

Borjas, George J., and Bratsberg, Bernt M., (November 1994) "Who Leaves? The

Outmigration of the Foreign Born," NBER Working Paper, No. 4913.

Chiswick, Barry R., (May 1999) "Are Immigrants Favorably Self-Selected?" The American Economic Review Papers and Proceedings, Vol. 89, No. 2, 181-185.

(April 1986a) "Is the New Immigration Less Skilled than the Old?" Journal of Labor Economics, Vol. 4, No. 2, 168-192.

(April 1986b) "Human Capital and the Labor Market Adjustment of Immigrants: Testing Alternative Hypotheses" in Research in Human Capital and Development, Stark, Oded, editor. Vol. 4, 1-26: JAI Press, Greenwich. 
(October 1980) "Immigrant Earnings Patterns by Sex, Race, and Ethnic

Groupings," Monthly Labor Review, Vol. 103, No. 10, 22-25.

(October 1978) "The Effect of Americanization on the Earnings of

Foreign-Born Men," Journal of Political Economy, Vol. 86, No. 5, 897-922.

(1978) "A Longitudinal Analysis of Occupational Mobility of Immigrants,"

in Proceedings of the $30^{\text {th }}$ Annual Industrial Relations Research Association Meeting,

Dennis, Barbara, editor. Madison: University of Wisconsin Press, 20-27.

(February 1977) "Sons of Immigrants: Are They at an Earnings

Disadvantage? (In Some Aspects of Income Distribution)" The American Economic

Review, Papers and Proceedings of the Eighty-ninth Annual Meeting of the American

Economic Association, Vol. 67, No. 1, 376-380.

Chiswick, Barry R., and Miller, Paul W., (February 1999)"Language Skills and Earnings among Legalized Aliens," Journal of Population Economics, Vol. 12, No. 1, 63-89.

(February 1996) "Ethnic Networks and Language Proficiency among Immigrants," Journal of Population Economics, Vol. 9, No. 1, 19-35.

Constant, Amelie, (December 1998) The Earnings of Male and Female Guestworkers and Their Assimilation into the German Labor Market: A Panel Study 1984-1993. Ph.D. Dissertation, Vanderbilt University.

(1998) "The Earnings of Male and Female Guestworkers and their

Assimilation into the West German Labor Market." Demographie Aktuell, 14. Berlin: Deutsches Institut fur Wirtschaftsforschung.

Constant, Amelie, and Massey, Douglas S., (October 2002) "Return Migration by German Guestworkers: Neoclassical versus New Economic Theories," International Migration, Vol. 40, No. 4, 5-38.

Duleep, Harriet Orcutt, (1994) "Social Security and the Emigration of immigrants," Social Security Bulletin, Vol. 57, No. 1, 37-52. 
Dustmann, Christian, (April 1996) "Return Migration-The European Experience," Economic Policy: A European Forum, Vol. 22, No. 1, S215-249.

(July 1993) "Return Intentions of Migrants: Theory and Evidence," University of Bielefeld, Discussion Paper, No. 274.

Edin, Per-Anders, LaLonde, Robert J., and Aslund, Olof, (2000) “Emigration of Immigrants and Measures of Immigrant Assimilation: Evidence from Sweden," Swedish Economic Review, Vol. 7, No. 2, 163-204.

Jasso, Guillermina, and Rosenzweig, Mark R., (1990) The New Chosen People: Immigrants in the United States. New York: Russell Sage Foundation.

(1988) "How Well do U.S. Immigrants do? Vintage Effects, Emigration

Selectivity, and Occupational Mobility of Immigrants," in Research of Population

Economics, Vol. 6, A Research Annual, Schultz, Paul T., editor. JAI Press, Greenwich, Connecticut and London. 229-253.

(1986c) "What's in a Name? Country-of-Origin Influences on the Earnings of Immigrants in the United States," in Research in Human Capital and Development, Vol. 4, A Research Annual, Oded Stark and Ismail Sirageldin editors. JAI Press, Greenwich, Connecticut and London. 75-106.

(August 1982) "Estimating the Emigration Rates of Legal Immigrants using Administrative and Survey Data: The 1971 Cohort of Immigrants to the United States," Demography, Vol. 19, No. 3, 279-290.

Licht, Georg, and Steiner, Viktor, (1994) "Assimilation, Labour Market Experience and Earnings Profiles of Temporary and Permanent Immigrant Workers In Germany." International Review of Applied Economics, Bol. 8, No. 2, 130-156.

Lillard, Lee A., and Willis, Robert J., (Fall 1994) "Intergenerational Educational Mobility," The Journal of Human Resources, Vol. 29, No. 4, 1130-1160. 
Lindstrom, David P., and Massey, Douglas S., (December 1994) "Selective Emigration, Cohort Quality, and Models of Immigrant Assimilation," Social Science Research, Vol. 23, No. $4,315-349$.

Massey, Douglas S., (May 1987) "Understanding Mexican Migration to the United States," American Journal of Sociology, Vol. 92, No. 6, 1332-1403.

Merkle, Lucie, and Zimmermann, Klaus F., (January 1992) "Savings, Remittances and Return Migration," Economics Letters, Vol. 38, No. 1, 77-81.

Pannenberg, Markus, (August 1998) "Documentation of Sample Sizes and Panel Attrition in the German Socio-Economic Panel (GSOEP) (1984 until 1997)," DIW Diskussionpapier, No. 172 .

Pischke, Jorn-Steffen, (September 1993) "Assimilation and the Earnings of Guestworkers In Germany." Discussion paper. Cambridge: Massachussetts Institute of Technology. Ramos, Fernando A., (1992) "Out-Migration and Return Migration of Puerto Ricans," in Immigration and the Work Force, Borjas, G. and Freeman, R. editors. University of Chicago Press.

Reagan, Patricia B, and Olsen, Randall J., (August 2000) "You Can Go Home Again: Evidence from Longitudinal Data," Demography, Vol. 37, No. 3, 339-350.

Schmidt, Christoph M., (Special 1997) "Immigrant Performance in Germany: Labor Earnings of Ethnic German Migrants and Foreign Guest-workers," Quarterly Review of Economics and Finance, Vol. 37, No. , 379-397.

(1/2 1994) "The Country of Origin, Family Structure and Return Migration of Germany's Guest-Workers," Proceedings of the 1993 International Conference of German Socio-Economic Panel Study Users, in Vierteljahrsheft zur Wirtschaftsforschung, Burkhauser, R. V., and Wagner, G. G., editors. Duncker and Humblot Berlin, 119-125. 
Sjaastad, Larry A., (October 1962) "The Costs and Returns of Human Migration," Journal of Political Economy, Vol. 70, No.5, Pt. 2, S80-S93.

Soep Group (2001) The German Socio-Economic Panel (GSOEP) after more than 15 years - Overview. In: Elke Host, Dean R. Lillard, and Thomas A DiPrete (eds): Proceedings of the 2000 Fourth International Conferences of German Socio-Economic Panel Study Users (GSOEP2000), Quarterly Journal of Economic Research, Vol. 70, No. 1, 7-14. Steiner, Viktor, and Velling, Johannes, (1994) "Re-Migration Behavior and Expected Duration of Stay of Guest Workers in Germany," in The Economic Consequences of Immigration to Germany, Steinmann, Gunter, and Ulrich, Ralph E., editors. Physica-Verlag, Heidelberg, 101-119.

Treiman, Donald J., (1977) Occupational Prestige in Comparative Perspective. New York: Academic Press.

Velling, Johannes, (1/2 1994) "The Determinants of Family Reunification among German Guest-Workers," Proceedings of the 1993 International Conference of German SocioEconomic Panel Study Users, in Vierteljahrsheft zur Wirtschaftsforschung, Burkhauser, R. V., and Wagner, G. G., editors. Duncker and Humblot Berlin, 126-132.

Warren, Robert, and Peck, Marks Jennifer, (1980) "Foreign-Born Emigration from the United States: 1960-1970," Demography, Vol. 17, No. 7, 1-84.

Warren, Robert, and Kraly, Ellen P., (1985) "The Elusive Exodus: Emigration from the United States," Population Trends and Public Policy, No. 8, Population Reference Bureau, Washington, DC. 


\section{IZA Discussion Papers}

\begin{tabular}{|c|c|c|c|c|}
\hline No. & Author(s) & Title & Area & Date \\
\hline 655 & $\begin{array}{l}\text { W. Arulampalam } \\
\text { R. A. Naylor } \\
\text { J. P. Smith }\end{array}$ & $\begin{array}{l}\text { Effects of In-Class Variation and Student Rank } \\
\text { on the Probability of Withdrawal: Cross-Section } \\
\text { and Time-Series Analysis for UK University } \\
\text { Students }\end{array}$ & 2 & $11 / 02$ \\
\hline 656 & $\begin{array}{l}\text { T. Beissinger } \\
\text { O. Büsse }\end{array}$ & $\begin{array}{l}\text { The Impact of the Unemployment Benefit } \\
\text { System on International Spillover Effects }\end{array}$ & 2 & $11 / 02$ \\
\hline 657 & $\begin{array}{l}\text { A. Kugler } \\
\text { J. F. Jimeno } \\
\text { V. Hernanz }\end{array}$ & $\begin{array}{l}\text { Employment Consequences of Restrictive } \\
\text { Permanent Contracts: Evidence from Spanish } \\
\text { Labor Market Reforms }\end{array}$ & 2 & $11 / 02$ \\
\hline 658 & $\begin{array}{l}\text { G. Brunello } \\
\text { R. Winter-Ebmer }\end{array}$ & $\begin{array}{l}\text { Why Do Students Expect to Stay Longer in } \\
\text { College? Evidence from Europe }\end{array}$ & 5 & $12 / 02$ \\
\hline 659 & $\begin{array}{l}\text { D. Byrne } \\
\text { E. Strobl }\end{array}$ & $\begin{array}{l}\text { Defining Unemployment in Developing } \\
\text { Countries: Evidence from Trinidad and Tobago }\end{array}$ & 4 & $12 / 02$ \\
\hline 660 & $\begin{array}{l}\text { E. Strobl } \\
\text { R. Thornton }\end{array}$ & $\begin{array}{l}\text { Do Large Employers Pay More in Developing } \\
\text { Countries? The Case of Five African Countries }\end{array}$ & 4 & $12 / 02$ \\
\hline 661 & $\begin{array}{l}\text { E. Strobl } \\
\text { F. Walsh }\end{array}$ & $\begin{array}{l}\text { Efficiency Wages and Effort: Are Hard Jobs } \\
\text { Better? }\end{array}$ & 3 & $12 / 02$ \\
\hline 662 & $\begin{array}{l}\text { E. Strobl } \\
\text { F. Walsh }\end{array}$ & $\begin{array}{l}\text { Getting It Right: Employment Subsidy or } \\
\text { Minimum Wage? }\end{array}$ & 3 & $12 / 02$ \\
\hline 663 & $\begin{array}{l}\text { A. B. Krueger } \\
\text { P. Zhu }\end{array}$ & $\begin{array}{l}\text { Another Look at the New York City School } \\
\text { Voucher Experiment }\end{array}$ & 6 & $12 / 02$ \\
\hline 664 & $\begin{array}{l}\text { J. R. Skaksen } \\
\text { A. Sørensen }\end{array}$ & $\begin{array}{l}\text { Skill Upgrading and Rigid Relative Wages: The } \\
\text { Case of Danish Manufacturing }\end{array}$ & 2 & $12 / 02$ \\
\hline 665 & H. Görg & $\begin{array}{l}\text { Fancy a Stay at the "Hotel California"? Foreign } \\
\text { Direct Investment, Taxation and Firing Costs }\end{array}$ & 2 & $12 / 02$ \\
\hline 666 & $\begin{array}{l}\text { P. Arnds } \\
\text { H. Bonin }\end{array}$ & $\begin{array}{l}\text { Frühverrentung in Deutschland: Ökonomische } \\
\text { Anreize und institutionelle Strukturen }\end{array}$ & 7 & $12 / 02$ \\
\hline 667 & $\begin{array}{l}\text { P. Arnds } \\
\text { H. Bonin }\end{array}$ & $\begin{array}{l}\text { Arbeitsmarkteffekte und finanzpolitische Folgen } \\
\text { der demographischen Alterung in Deutschland }\end{array}$ & 7 & $12 / 02$ \\
\hline 668 & $\begin{array}{l}\text { J. Meckl } \\
\text { S. Zink }\end{array}$ & $\begin{array}{l}\text { Solow and Heterogeneous Labor: A } \\
\text { Neoclassical Explanation of Wage Inequality }\end{array}$ & 3 & $12 / 02$ \\
\hline 669 & $\begin{array}{l}\text { A. C. D'Addio } \\
\text { I. De Greef } \\
\text { M. Rosholm }\end{array}$ & $\begin{array}{l}\text { Assessing Unemployment Traps in Belgium } \\
\text { Using Panel Data Sample Selection Models }\end{array}$ & 2 & $12 / 02$ \\
\hline 670 & $\begin{array}{l}\text { M. Botticini } \\
\text { Z. Eckstein }\end{array}$ & $\begin{array}{l}\text { From Farmers to Merchants: A Human Capital } \\
\text { Interpretation of Jewish Economic History }\end{array}$ & 5 & $12 / 02$ \\
\hline 671 & $\begin{array}{l}\text { A. Constant } \\
\text { S. Konstantopoulos }\end{array}$ & $\begin{array}{l}\text { School Effects and Labor Market Outcomes for } \\
\text { Young Adults in the 1980s and 1990s }\end{array}$ & 1 & $12 / 02$ \\
\hline 672 & $\begin{array}{l}\text { A. Constant } \\
\text { D. Massey }\end{array}$ & $\begin{array}{l}\text { Self-Selection, Earnings, and Out-Migration: } \\
\text { A Longitudinal Study of Immigrants to Germany }\end{array}$ & 1 & $12 / 02$ \\
\hline
\end{tabular}

An updated list of IZA Discussion Papers is available on the center's homepage www.iza.org. 